SAND76-0427

NUREG766510

Unlimited Release
DISTRIBUTION

CATEGORY NRC-12

\title{
Shock and Vibration Environments for Large Shipping Containers on Rail Cars and Trucks
}

Clifford F. Magnuson, Leonidas T. Wilson

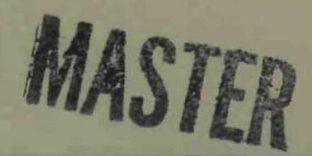

Prepared by Sandia Laboratories, Albuquerque, New Mexico 87115

and Livermore, California 94550, for the United States Nuclear

Regulatory Commission under ERDA Contract E(29-1)-789

Printed July 1977

\section{Sandia Laboratories}

Nuclear Fuel Cycle Programs 
Issued by Sandia Laboratories, operated for the United States Energy Research and Development Administration by Sandia Corporation.

NOTICE

This report was prepared as an account of work sponsored by the United States Government. Neither the United States nor the United States Energy Research and Development Administration, nor the United States Nuclear Regulatory Commission, nor any of their employees, nor any of their contractors, subcontractors, or their employees, makes any warranty, expressed or implied, or assumes any legal liability or responsibility for the accuracy, completeness or usefulness of any information, apparatus, product or process disclosed, or represents that its use would not infringe privately owned rights.

Available from

National Technical Information Service Springfield, Virginia 22161 


\section{DISCLAIMER}

This report was prepared as an account of work sponsored by an agency of the United States Government. Neither the United States Government nor any agency Thereof, nor any of their employees, makes any warranty, express or implied, or assumes any legal liability or responsibility for the accuracy, completeness, or usefulness of any information, apparatus, product, or process disclosed, or represents that its use would not infringe privately owned rights. Reference herein to any specific commercial product, process, or service by trade name, trademark, manufacturer, or otherwise does not necessarily constitute or imply its endorsement, recommendation, or favoring by the United States Government or any agency thereof. The views and opinions of authors expressed herein do not necessarily state or reflect those of the United States Government or any agency thereof. 


\section{DISCLAIMER}

Portions of this document may be illegible in electronic image products. Images are produced from the best available original document. 
SAND 76 0427

NUREG766510

unlimited Rélease

\title{
SHOCK AND VIBRATION ENVIRONMENTS \\ FOR LARGE SHIPPING CONTAINERS \\ ON RAII CARS AND TRUCKS*
}

\author{
C. F. Magnuson \\ Applied Mechanics Division II -1282 \\ I. T. Wilson \\ Applied Mechanics Division III - 1284 \\ Sandia Laboratories \\ Albuquerque, New Mexico 87115 \\ Printed June, 1977
}

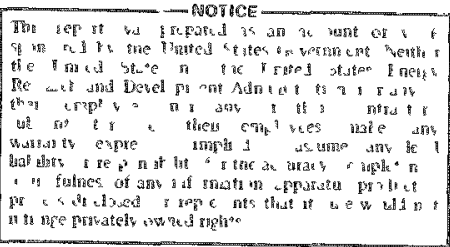

ABSTRACT

The purpose of this study was to provide definitions of shock and vibration environment to which fissile material shipping containers may be exposed during normal shipment by truck and rail cars. The definitions of vibration, shock superimposed on vibration and rail coupling shock result from existing data. The dependence of shock environment, from rail coupling operations, on parameters like cargo weight and shock attenuation couplers was also studied using spring-mass models. These studies show that for rail cars equipped with standard draft gear, the cargo response decreases with increased cargo weight until the springs bottom out. For rail cars equipped with shock attenuation couplers, cargo weight has little effect on cargo response. The study also shows the importance of matching couplers and tiedown stiffnesses to decrease the cargo response. Vibration and shock data samples have been obtained during truck shipment of heavy cargo and the data will be presented in subsequent reports. Similar data need to be obtained for rail shipment of heavy cargo and during rail coupling operations with heavy cargo.

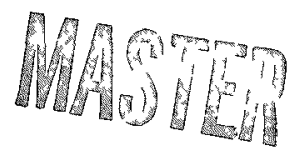

Whis work was sponsored by the Division of Safeguards, Fuel Cycle and Environmental Research of the United States Nuclear Regulatory Commission; Contract No. A-1049-6. 


\section{ACKNOWLEDGEMENTS}

The authors gratefully acknowledge the contributions made to this study by C. A. Davidson, J. T. Foley, E. I. Harley, M. Huerta, S. E. Benzley, R. T. Othmer, T. I. Paez, T. G. Priddy, R, Rodeman, and W. A. Von Riesemann. 
TABLE OF CONTENTS

\begin{tabular}{|c|c|c|}
\hline \multicolumn{2}{|l|}{ FOREWORD } & 10 \\
\hline \multicolumn{2}{|l|}{ SUMMARY } & 11 \\
\hline \multirow[t]{10}{*}{ CHAPTER I } & $\begin{array}{l}\text { Vibration and shock Environments Encountered } \\
\text { During Truck and Rail Transportation }\end{array}$ & 13 \\
\hline & Definitions of Dynamic Environments & 13 \\
\hline & Explanation of Data & 13 \\
\hline & Truck Data & 14 \\
\hline & Vibration & 14 \\
\hline & Shock & 15 \\
\hline & Rail Data & 16 \\
\hline & Vibration & 16 \\
\hline & Shock & 17 \\
\hline & $\begin{array}{l}\text { Superimposed Shock } \\
\text { Rail Coupling Shock }\end{array}$ & $\begin{array}{l}17 \\
18\end{array}$ \\
\hline \multirow[t]{7}{*}{ CHAPTER II } & Single Pulse Representation of Shock & 24 \\
\hline & Method & 24 \\
\hline & $\begin{array}{l}\text { Shocks Represented by single Half-Sine } \\
\text { Pulses }\end{array}$ & 26 \\
\hline & Truck & 26 \\
\hline & Rail & 26 \\
\hline & Rail Shock Superimposed on Vibration & 26 \\
\hline & Rail shock from coupling Operations & 26 \\
\hline \multirow[t]{10}{*}{ CHAPTER III } & $\begin{array}{l}\text { Dynamic Analysis of Shock Environment of } \\
\text { Rail Cars During Coupling Operations }\end{array}$ & 28 \\
\hline & Spring-Mass Mathematical Models & 28 \\
\hline & Spent Fuel Cask System & 28 \\
\hline & Mathematical Model & 29 \\
\hline & ATMX Car & 31 \\
\hline & Mathematical Model & 31 \\
\hline & Analytical Results & 32 \\
\hline & Spent Fuel Cask System & 32 \\
\hline & ATMX Car & 35 \\
\hline & Conclusions & 39 \\
\hline REFERENCES & & 40 \\
\hline PENDIX & Computer-Generated Response Spectra & 41 \\
\hline
\end{tabular}


Number

VI Half-sine Pulses for the spent Fuel Cask system with Free Travel Space

VII Half-Sine Pulses for the spent Fuel Cask system with Cask Tied Down

VIIT Half-Sine Pulses for ATMX System with standard Draft Gear

TX Half-sine Pulses for ATMX System with .38 metre (15-inch) Hydraulic End-of-Car Couplers

\section{ILLUSTRATIONS}

Figure

1 Truck Superimposed Shock Response Envelopes 3\% Damping

2 Rail Superimposed Shock Response Envelopes 3: Damping

3 Railroad Coupling Shock Response Spectrum 3\% Damping - ATMX-500-8.45 km/hr (5.25 mph) Impact Vertical Axis

4 Railroad Coupling Shock Response Spectrum 3: Damping - ATMX-500 - $10.78 \mathrm{~km} / \mathrm{hr}(6.7 \mathrm{mph})$ Impact Vertical Axis

5 Railroad Coupling shock Response Spectrum 3: Damping - ATMX-500 - $14.21 \mathrm{~km} / \mathrm{hr}$ (8.83 mph) 1 mpact Vertical Axis

Railroad Coupling Shock Response Spectrum 3: Damping - ATMX-500-17.78 km/hr (11.05 mph) Impact Vertical Axis

7 Railroad Coupling Shock Response Spectrum 3\% Damping - ATMX-500-8.45 km/hr (5.25 mph) Impact Longitudinal. Axis 
Railroad Coupling Shock Response Spectrum 38 Damping - ATMX-500 - $10.78 \mathrm{~km} / \mathrm{hr}(6.7 \mathrm{mph})$ Impact - Longitudinal Axis

Railroad Coupling Shock Response spectrum 3 . Damping - ATMX-500 - $14.21 \mathrm{~km} / \mathrm{hr}$ (8.83 mph) Impact - Longitudinal Axis

Railroad Coupling Shock Response spectrum 3\% Damping - ATMX-500-17.78 km/hr (11.05 mph) Impact - Longitudinal Axis

11 Single Degree of Freedom Response Spectrum Half-Sine Pulse - 3\% Damping

12 Test Data Response Spectra Enveloped by Simple Pulse Response Spectrum

Shear structure clearance

Spring-Mass Model: Spent Fuel Cask System

Spring-Mass Model; ATMX-600 Rail Car with Two Fuel Casks

Shock Response Spectra - ATMX-500 and ATMX-600 Composite Spectra - 3\% Damping - $17.70 \mathrm{~km} / \mathrm{hr}$ (11 mph) Impact - Longitudinal Axis

Peak Acceleration and Pulse Duration; Half-Sine Pulses - Spent Fuel Cask System Longitudinal Axis

Peak Acceleration and Pulse Duration: Half-Sine Pulses - ATMX System - Longitudinal Axis

A-1 Response Spectrum - Analytical Results. Spent Fuel Cask System with $3.2 \mathrm{~mm}$ (1/8 inch) Spacing, $178,000 \mathrm{~N}(40,000$ pound $)$ Cargo, $17.78 \mathrm{~km} / \mathrm{hr}$ (11.05 mph) Impact Velocity 3 percent Damping, Longitudinal Axis

A-2 Response Spectrum - Analytical Results. Spent Fuel Cask system with $3.2 \mathrm{~mm}$ ( $1 / 8$ inch) Spacing, $445,000 \mathrm{~N}(100,000$ pound) Cargo, $17.78 \mathrm{~km} / \mathrm{hr}$ (11.05 mph) Impact Velocity, 3 percent Damping. Longitudinal Axis

A-3 Response Spectrum -- Analytical Results. Spent Fuel Cask System with $3.2 \mathrm{~mm}$ ( $1 / 8$ inch) Spacino, $712,000 \mathrm{~N}(160,000$ pound) Cargo, $17.78 \mathrm{~km} / \mathrm{hr}$ (11.05 mph) Impact Velocity, 3 percent Damping. Longitudinal Axis

A-4 Response Spectrum -- Analytical Results. Spent Fuel Cask System with $3.2 \mathrm{~mm}$ ( $1 / 8$ inch) Spacing, $890,000 \mathrm{~N}(200,000$ pound) Cargo, $17.78 \mathrm{~km} / \mathrm{hr}$ (11.05 mph) Impact Velocity, 3 percent Damping. Longitudinal Axis 
Figure

Response Spectrum -- Analytical Results. Spent Fuel Cask System, Cargo Tied Down, 178,000 N $(40,000$ pound) Cargo, $17.78 \mathrm{~km} / \mathrm{hr}$ (11.05 mph) Impact Velocity, 3 percent Damping, Longitudinal Axis

A-6 Response Spectrum -- Analytical Results. Spent Fuel Cask System, Cargo Tied Down, 445,000 N (100,000 pound) Cargo, $17.78 \mathrm{~km} / \mathrm{hr}(11.05 \mathrm{mph})$ Impact Velocity, 3 percent Damping, Longitudinal Axis

A-7 Response Spectrum -- Analytical Results. Spent Fuel Cask System, Cargo Tied Down, 712,000 N (160,000 pound) Cargo, $17.78 \mathrm{~km} / \mathrm{hr}$ (11.05 mph) Impact Velocity, 3 percent Damping, Longitudinal Axis

A-8 Response Spectrum -- Analytical Results. Spent Fuel Cask System, Cargo Tied Down, 890,000 IN (200,000 pound) Cargo, $17.78 \mathrm{~km} / \mathrm{hr}$ (11.05 mph) Impact velocity, 3 percent Damping, Longitudinal Axis

A-9 Response Spectrum -- Analytical Results. ATMX Car, Standard Draft Gear, $178,000 \mathrm{~N}(40,000$ pound) Cargo, $17.78 \mathrm{~km} / \mathrm{hr}$ (11.05 mph) Impact Velocity, 3 percent Damping, Longitudinal Axis

A-10 Response Spectrum -- Analytical Results. ATMX Car, Standard Draft Gear, 451,000 N (101,300 pound) Cargo, $17.78 \mathrm{~km} / \mathrm{hr}$ (11.05 mph) Impact Velocity, 3 percent Damping, Longitudinal Axis

A-11 Response Spectrum -- Analytical Results. ATMX Car, Standard Draft Gear, $712,000 \mathrm{~N}(160,000$ pound) Cargo, $17.78 \mathrm{~km} / \mathrm{hr}$ (11.05 mph) Impact Velocity, 3 percent Damping, Longitudinal Axis

A-12 Response Spectrum -- Analytical Results. ATMX Car, Standard Draft Gear, $890,000 \mathrm{~N}(200,000$ pound)

Carqo, $17.78 \mathrm{~km} / \mathrm{hr}$ (11.05 mph) Impact velocity, 3 percent Damping, Longitudinal Axis

A-13 Response Spectrum -- Analytical Results. ATMX Car, Shock Attenuating Couplers, 178,000 N $(40,000$ pound) Cargo, $17.78 \mathrm{~km} / \mathrm{hr}$ (11.05 mph) Impact Velocity, 3 percent Damping, Longitudinal Axis

A-14 Response Spectrum -- Analytical Results. ATMX Car, Shock Attenuating Couplers, 451,000 N $(101,300$ pound) Cargo, $17.78 \mathrm{~km} / \mathrm{hr}$ (11.05 mph) Impact Velocity, 3 percent Damping, Longitudinal Axis

A-15 Response Spectrum -- Analytical Results. ATMX Car, Shock Attenuating Couplers, $712,000 \mathrm{~N}(160,000$ pound) Cargo, $17.78 \mathrm{~km} / \mathrm{hr}$ (11.05 mph) Impact Velocity, 3 percent Damping, Longitudinal Axis 
A-16 Response spectrum - Analytical Results. ATMX Car, Shock Attenuating Couplers, $890,000 \mathrm{~N}(200,000$ pound) Cargo, $17.78 \mathrm{~km} / \mathrm{hr}$ (11.05 mph) Impact Velocity, 3 percent Damping, Longitudinal Axis 


\section{FOREWORD}

Packaging and transport of fissile radioactive materials are regulated by the U.S. Nuclear Regulatory Commission by means of Code of Federal Regulations Title 10, Part 71. Appendix A of these regulations specifies environmental conditions of transport to be applied to determine theix effects on packages of radioactive materials. However, the appendix does not specify numerically the frequencies or amplitudes of vibration and shock environments nor does it mention their expected occurrence rate as a function of shipment time and/or mileage. As a result, when evaluating a package for licensing applications, assumptions regarding these environments must be made by each applicant.

To provide guidance in this area, the U.S. Nuclear Regulatory Commission contracted with sandia Laboratories to gather and evaluate data regarding truck and rail shock and vibration environments normally encountered in transporting large shipping casks. The project is divided into three tasks:

(1) Extract, review, and reduce shock and vibration environment definitions currently on file in both the ERDA/DOD and ERDA Transportation Environment Data Banks. Determine the best. simply stated estimates of environments for large shipping containers on truck and rail car.

(2) Conduct dynamic analyses of the shock environment experienced by cargo in rail switching and coupling to identify the dependence of the shock environment on heavy cargo weights and on shock attenuation couplers. The results are to be used to refine furthcr the shock load description. Existing mathematical models of freight cars will be altered to study these special concerns.

(3) Identify during the performance of Tasks 1 and 2 the need for additional data. The tests which are necessary to obtain these data are to be planned. Actual measurements will be obtained on a "piggyback" basis.

Tasks (1) and (2) are addressed in this report. Task (3) will be addressed in subsequent reports.

All data used in this report as well as the analyses conducted were based on English units. The metric (SI) units presented are approximate conversions from the English units. 


\section{SUMMARY}

This report contains descriptions of shock and vibration to which shipping containers may be exposed during normal shipment by rail and truck. The data and analyses presented encompass (1) investigations of existing shock and vibration data in the ERDA/DOD and ERDA Transportation Data Banks and (2) analytical studies of the shock environment experienced by cargo to determine the dependence of the environment on cargo weight, tiedowns, and shock attenuation couplers.

Vibration data investigated for this report show the highest expectancy level of cargo vibration to be:

\begin{tabular}{|c|c|c|c|}
\hline Carrier & Axis & $\begin{array}{c}0 \text { to Peak } \\
\text { Maximum } \\
\text { Acceleration }(\mathrm{g})\end{array}$ & $\begin{array}{l}\text { Frequency } \\
\text { Range (Hz) }\end{array}$ \\
\hline \multirow[t]{3}{*}{ Truck } & Longitudinal & 1.50 & $0-1900$ \\
\hline & Transverse & 1.17 & $0-1900$ \\
\hline & Vertical & 2.00 & $0-1900$ \\
\hline \multirow[t]{3}{*}{ Rail Car } & Longitudinal & 0.19 & $0-$ \\
\hline & Transverse & 0.19 & $0-$ \\
\hline & Vertical & 0.37 & $0-$ \\
\hline
\end{tabular}

The shock data investigated show the following simple half-sine input pulses which conservatively represent the maximum expected shock severities:

\begin{tabular}{|c|c|c|c|}
\hline Carrier & Axis & $\begin{array}{c}\text { Peak } \\
\text { Acceleration } \\
\text { (g) }\end{array}$ & $\begin{array}{l}\text { Pulse } \\
\text { Duration } \\
\text { (ms) }\end{array}$ \\
\hline \multirow{3}{*}{$\begin{array}{l}\text { Truck } \\
\text { (Shocks super- } \\
\text { imposed on } \\
\text { Vibration) }\end{array}$} & Longitudinal & 2.8 & 20 \\
\hline & Transverse & 2.3 & 19 \\
\hline & Vertical & 7.0 & 77 \\
\hline $\begin{array}{l}\text { Rail Car } \\
\text { (Shocks } \\
\text { superim- } \\
\text { posed on } \\
\text { vibration) }\end{array}$ & Al1 & 4.7 & 14 \\
\hline $\begin{array}{l}\text { Rail Coup- } \\
\text { ling }\end{array}$ & Longitudinal & 39.0 & 18 \\
\hline $\begin{array}{l}17.78 \mathrm{~km} / \mathrm{hr} \\
(11.05 \mathrm{mph})\end{array}$ & Vertical & 26.0 & 9 \\
\hline
\end{tabular}

Analyses of coupling operations for two rail shipment combinations, the first a rail car with a representative spent fuel cask system and the second an ATMX car with two radioactive waste material containers, showed that, for rail cars equipped with standard draft 
gear, shock environments at the cargo decrease as cargo weight increases until the coupler springs bottom out. For rail cars equipped with shock attenuation couplers, there is little variation in shock severity throughout the range of weights for which the analyses were conducted. These analyses also showed that cargo should be tied securely to the rail car to prevent relative motion between the cargo and the car followed by stiff impact of the cargo against car structure. 
CHAPTER I

VIBRATION AND SHOCK ENVIRONMENTS ENCOUNTERED

DURING TRUCK AND RAII TRANSPORTATION

The environmental descriptions presented in this chapter are summaries of data from the ERDA/DOD and ERDA Transportation Data Banks. The data were gathered on different modes of transport for use in defining the environments to which weapons may be exposed. Since about 1960 these data have been obtained from literature sources and, to a large extent, measured, reduced, and analyzed by the Engineering Analysis Department of Sandia Laboratories.

\section{Definitions of Dynamic Environments}

Dynamic excitations delivered to cargo may be described as a mixture of vibration, occasional shock superimposed on the vibration and isolated shock which occurs in single events such as rail coupling. Vibration is the excitation which occurs whenever the carrier is in motion and is produced by the carrier suspension system and carrier frame members reacting to travel over surface irregularities in highways or railroads as well as the vibration generated by the carrier motive system.

Superimposed shock is that which often results in higher amplitudes of cargo response than that produced by vibration. Characteristically it consists of decaying transient pulses which are superimposed and intermixed with the vibration. For trucks the superimposed shock is produced by crossing railroad tracks, bridge approaches, and cattle guards and by striking pot holes. For rail cars the superimposed shock is produced by run-in and run-out and by crossing bridges, switches, and other track incersections.

shock resulting from rail coupling operations is significantly more severe than that which is superimposed and intermixed with the vibration; however, it occurs less frequently.

\section{Fxplanation of Data}

Vibration definitions presented herein are 0 to peak acceleration amplitude levels which envelope 99 percent of all amplitudes measured in each frequency band. The remaining one percent of the data was 
considered to represent superimposed shock and was treated separately. The distribution of the 99 percent acceleration amplitudes in each frequency band is random for which the probability distribution is very nearly Gaussian. The acceleration amplitudes were measured at the interface between the cargo and the cargo floor.

The data for shock were reduced in single-degree-of-freedom response spectra format. These spectra predict the maximum acceleration amplitude at which various single-degree-of-freedom systems would respond when subjected to the transient inputs. Response spectra are used because they permit translation of complex input into a more useful engineering format and permit statistical analysis of diverse individual phenomena. In these response spectra, three percent damping was used because our experience shows this to be representative of the response of metal to metal connections.

\section{Truck Data}

Vibration

The vibration data presented were obtained from over-the-road tests

using seven different truck and tractor-trailer configurations ${ }^{1,2]}$. The trucks were equipped with both conventional spring suspension systems and air-cushioned suspension systems. The cargo weights varied from no load to $133,000 \mathrm{~N}$ (15 tons). The trucks traveled over 2-lane highways, interstate highways, and secondary roads. Speeds varied over these different road types.

The highest of the 99 percent 0 to peak acceleration amplitudes of $2 \mathrm{~g}$ were found to occur in the vertical axis in the $0-5 \mathrm{~Hz}$ frequency band. The amplitude levels in the vertical axis decreased to below $1 \mathrm{~g}$ between 80 and $700 \mathrm{~Hz}$ and then increased to $1.17 \mathrm{~g}$ between 700 to $1400 \mathrm{~Hz}$ and again decreased to $.87 \mathrm{~g}$ in the 1400 to $1900 \mathrm{~Hz}$ frequency band.

The highest of the 99 percent 0 to peak acceleration amplitude levels of $1.5 \mathrm{~g}$ in the longitudinal axis occurred in the 700 to 1000 $\mathrm{Hz}$ frequency band. In this axis the second highest amplitude of 1.23 $\mathrm{g}$ occurred in the 120 to $180 \mathrm{~Hz}$ frequency band. The acceleration amplitudes in all other frequency bands were $0.87 \mathrm{~g}$ or lower.

The 99 percent 0 to peak acceleration amplitude levels in the transverse or lateral axis were below $0.42 \mathrm{~g}$ up to $700 \mathrm{~Hz}$, increased to $0.87 \mathrm{~g}$ in the 700 to $1000 \mathrm{~Hz}$ frequency band and $1.17 \mathrm{~g}$ in the 1000 to $1400 \mathrm{~Hz}$ frequency band, then decreased to $0.24 \mathrm{~g}$ in the 1400 to $1900 \mathrm{~Hz}$ frequency band. A tabular summary of the 99 percent 0 to peak 
acceleration amplitude levels for the three axes discussed above are presented in Table $I$.

TABLE I

\section{TRUCK VIBRATION}

Frequency

Band $(\mathrm{Hz})$

$$
0-5
$$

$5-10$

$10-20$

$20-40$

$40-80$

$80-120$

$120-180$

$180-240$

$240-350$

$350-500$

$500-700$

$700-1000$

$1000-1400$

$1400-1900$
Measurements on Cargo Floor $(g)$ 99: Level of 0 to Peak Amplitude

\begin{tabular}{|c|c|c|}
\hline $\begin{array}{c}\text { Longitudinal } \\
\text { Axis }\end{array}$ & $\begin{array}{c}\text { Transverse } \\
\text { Axis } \\
\end{array}$ & $\begin{array}{c}\text { Vertical } \\
\text { Axis } \\
\end{array}$ \\
\hline 0.10 & 0.10 & 2.00 \\
\hline 0.08 & 0.06 & 1.04 \\
\hline 0.84 & 0.15 & 1.68 \\
\hline 0.51 & 0.24 & 1.20 \\
\hline 0.36 & 0.42 & 0.50 \\
\hline 0.24 & 0.27 & 0.87 \\
\hline 1.23 & 0.21 & 0.63 \\
\hline 0.87 & 0.12 & 0.87 \\
\hline 0.24 & 0.15 & 0.63 \\
\hline 0.24 & 0.15 & 0.42 \\
\hline 0.87 & 0.15 & 0.87 \\
\hline 1.50 & 0.87 & 1.17 \\
\hline 0.87 & 1.17 & 1.17 \\
\hline 0.39 & 0.24 & 0.87 \\
\hline
\end{tabular}

Shock

The shock data presented were obtained from the same tests as the truck vibration data, but from different events. The shock data were obtained from measurements taken when the trucks encountered potholes, railroad crossings, and bridge approaches. The data presented define the response at the interface of the cargo and the cargo floor.

The vertical axis produced the highest predicted cargo response of the three axes across the complete frequency spectrum from 1 to 150 $\mathrm{Hz}$. The predicted cargo response in the other two axes are very similar to each other. The response spectra for all three axes are shown in Figure 1. Surveys of interstate highways in colorado, Utah, Wyoming, and New Mexico show a potential of superimposed shock-producing road irregularities occurring approximately once per $1.61 \mathrm{~km}$ (one mile) of travel. 


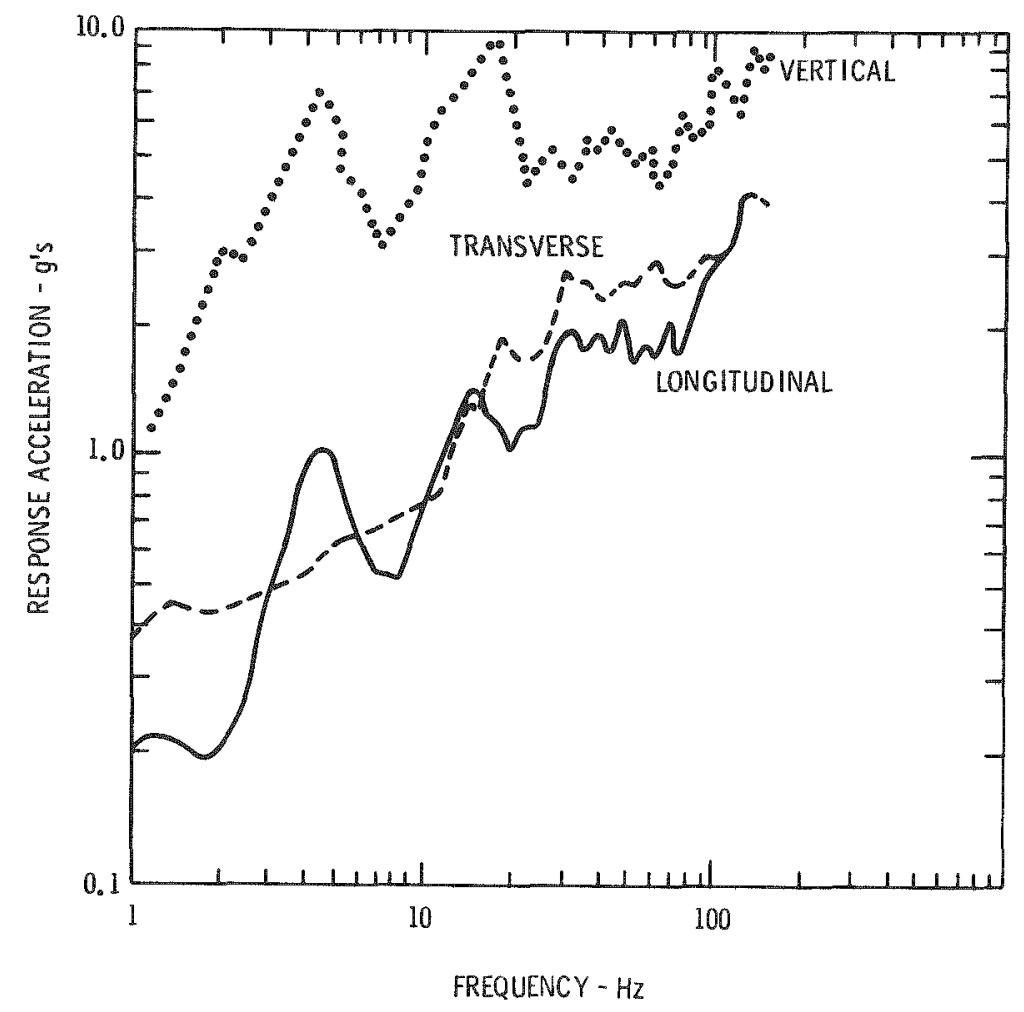

Figure 1. Truck superimposed Shock Response Envelopes -- 3\% Damping

\section{$\underline{\text { Rail Data }}$}

\section{Vibration}

The vibration data presented herein were obtained during a shipment of a $133,000 \mathrm{~N}$ (15-ton) fuel cask positioned at the center of a USAX car ${ }^{[3]}$. The shipment was made over normal rail routes from paducah, kentucky to oak Ridge, Tennessee. The cask was tied down by tie-rods which extended through the floor of the car and attached to plates which had been welded to the car frame. The instrumented rail car was attached to three different trains. Their lengths varied from 65 to 120 cars during the trip.

The highest 99 percent 0 to peak acceleration amplitude level of $0.37 \mathrm{~g}$ occurred in the vertical axis. The vertical axis produced the same as or greater acceleration amplitudes than the other axes over the entire frequency spectrum of 0 to $350 \mathrm{~Hz}$. The amplitude levels are generally lower than for trucks in all three axes and do not vary significantly over the 0 to $350 \mathrm{~Hz}$ frequency spectrum. Data were not reduced above $350 \mathrm{~Hz}$ but interpretations indicated that the acceleration amplitude distributions above $350 \mathrm{~Hz}$ are similar to those in the 250 
to $350 \mathrm{~Hz}$ frequency Dand. Details of the 0 to peak acceleration amplitudes which encompass 99 percent of vibrations in specified frequency bands between 0 and $350 \mathrm{~Hz}$ are presented in Table II.

TABLE II

TRAIN VIBRATION

\section{Erequency \\ Band ( $\mathrm{Hz})$}

$$
\begin{gathered}
0-5 \\
5-10 \\
10-20 \\
20-30 \\
30-45 \\
45-60 \\
60-87 \\
87-125 \\
125-175 \\
175-250
\end{gathered}
$$

\begin{tabular}{|c|c|c|}
\hline $\begin{array}{c}\text { Longitudinal } \\
\text { Axis }\end{array}$ & $\begin{array}{c}\text { Transverse } \\
\text { Axis }\end{array}$ & $\begin{array}{c}\text { Vertical } \\
\text { Axis }\end{array}$ \\
\hline 0.14 & 0.14 & 0.37 \\
\hline 0.072 & 0.072 & 0.14 \\
\hline 0.072 & 0.072 & 0.10 \\
\hline 0.10 & 0.10 & 0.27 \\
\hline 0.19 & 0,14 & 0.37 \\
\hline 0.10 & 0.10 & 0.27 \\
\hline 0.10 & 0.19 & 0.19 \\
\hline 0.10 & 0.19 & 0.19 \\
\hline 0.10 & 0.10 & 0.19 \\
\hline 0.10 & 0.14 & 0.14 \\
\hline 0.10 & 0.10 & 0.14 \\
\hline
\end{tabular}$$
250-350
$$

In a report describing research rail rimation tests conducted on specially prepared tracks [4], it was concluded that as cargo weight on rail cars increases, vibration amplitudes in the car body decrease. To determine the trend of this reduction over normal railroad routes, additional tests with heavy cargo need to be conducted.

Shock

The shock descriptions presented are shown in single-degree-offreedom response spectra as was done for trucks. Two shock descriptions for rail are provided. The first is for shock which is superimposed on vibration and the second is for shock resulting from rail coupling operations.

Superimposed Shock - The data presented for shock which is superimposed on vibration were obtained during the same test described under rail vibration, but for different events. These events included crossing rail joints, traveling through switches, and run-in and run-out. The data describe the response at the interface of the cargo and the cargo floor. 
The levels of response are similar in all three axes in the frequency range between 3 and $150 \mathrm{~Hz}$ for which data were reduced. The response spectra envelopes for all three axes are shown in Figure 2. Analysis of data obtained during train transport of cars which were uniformly loaded with heavy cargo shows run-in and run-out events which may produce the levels of response shown occurring at an average rate of 9 times per $161 \mathrm{~km}$ (100 miles) of travel. Data to provide estimates for the frequency of crossing rail joints and travel throuqh switches are not availakle.

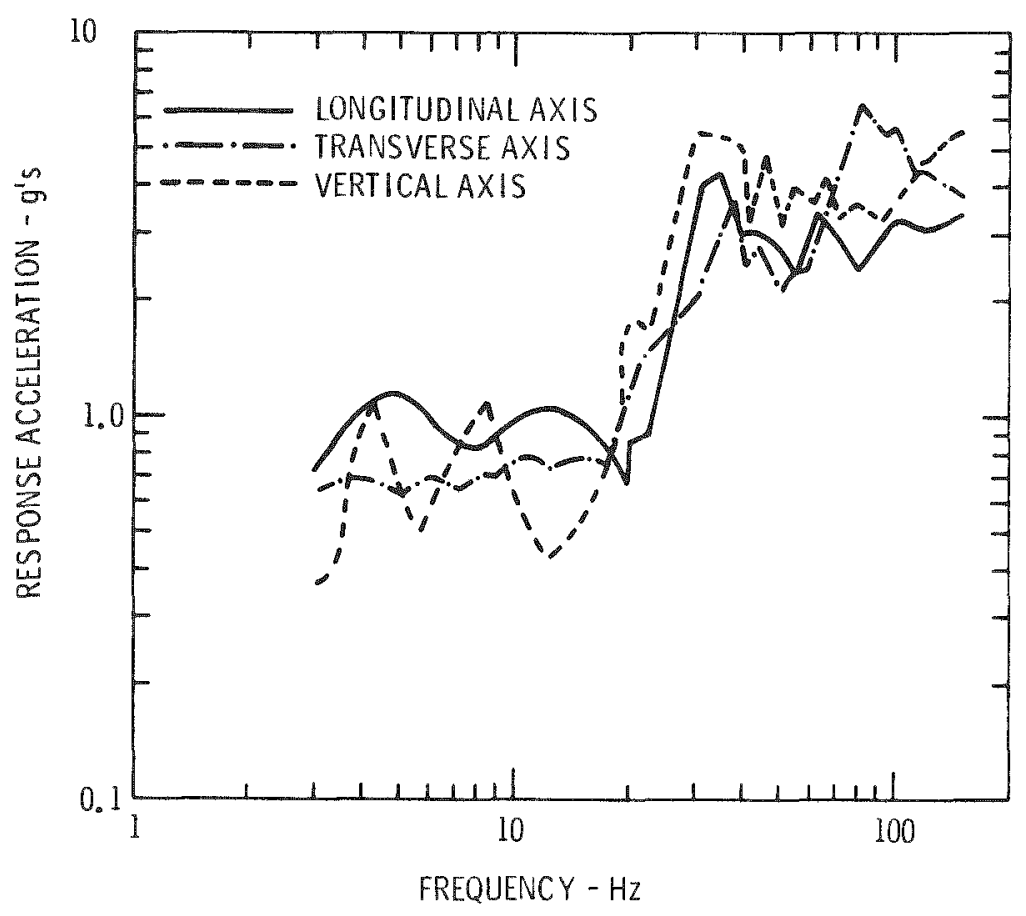

Figure 2. Rail Superimposed Shock Response Envelopes -- 3\% Damping

Rail Coupling Shock - Data for rail coupling shock were obtained from tests which had been conducted in the early 1960's using ATMX cars. The cargo was relatively light (approximately $44,500 \mathrm{~N}$ (10,000 pounds) to represent weapons. These tests were conducted at coupling speeds of $8.45,10.78,14.21$, and $17.78 \mathrm{~km} / \mathrm{hr}(5.25,6.7,8.83$, and $11.05 \mathrm{mph}$ respectively). Compilation of data from 15,648 switching and coupling operations $[5,6,7,8]$ presented in Table III showed that 63.5 percent of the observed coupling velocities were below $8.45 \mathrm{~km} / \mathrm{hr}(5.25 \mathrm{mph})$; nearly 90 percent were at or below $10.78 \mathrm{~km} / \mathrm{hr}(6.7 \mathrm{mph})$; 98 percent 
were below $14.21 \mathrm{~km} / \mathrm{hr}(8.83 \mathrm{mph})$; and 99.8 percent were below 17.78 $\mathrm{km} / \mathrm{hr}(11.05 \mathrm{mph})$.

Data obtained from the tests were considered applicable for presentation in this report even though the code of Federal Regulations (CFR) 49. Part 174.589 (c) states that cars transporting radioactive material are to be coupled together with a force no greater than that necessary to complete the coupling. This force is not specified.

Rail cars are designed to withstand impacts which produce 5,560,300 $\mathbb{N}(1,250,000$ pounds force) at the coupler or impact velocities up to $22.53 \mathrm{~km} / \mathrm{hr}(14 \mathrm{mph})^{[9]}$ and the observed coupling operations included impact velocities of $27.36 \mathrm{~km} / \mathrm{hr}(17 \mathrm{mph})$ with 99.8 percent at or below $17.70 \mathrm{~km} / \mathrm{hr}$ (11 $\mathrm{mph})$.

TABLE III

OBSERVED IMPACT VELOCITIES DURING RAII COUPLING

\begin{tabular}{|c|c|c|c|c|}
\hline $\begin{array}{l}\quad \text { Obse } \\
\text { Impact } \\
(\mathrm{km} / \mathrm{hr})\end{array}$ & $\begin{array}{l}\text { rved } \\
\text { Speeds } \\
\quad(m p b)\end{array}$ & $\begin{array}{l}\text { Number } \\
\text { Reported. }\end{array}$ & $\begin{array}{l}\text { Percent } \\
\text { of Total }\end{array}$ & $\begin{array}{l}\text { Cumulative } \\
\text { Percent }\end{array}$ \\
\hline$\leq 8.05$ & $\leq 5$ & 9936 & 63.5 & 63.5 \\
\hline 9.66 & 6 & 2831 & 18.1 & 81.6 \\
\hline 11.27 & 7 & 1331 & 8.5 & 90.1 \\
\hline 12.87 & 8 & 748 & 4.8 & 94.9 \\
\hline 14.48 & 9 & 492 & 3.1 & 98.0 \\
\hline 16.09 & 10 & 208 & 1.3 & 99.3 \\
\hline 17.70 & 11 & 73 & 0.5 & 99.8 \\
\hline 19.31 & 12 & 1 & 0.01 & 99.8 \\
\hline 20.92 & 13 & 20 & 0.1 & 99.9 \\
\hline 22.53 & 14 & 3 & 0.02 & 99.9 \\
\hline 24.14 & 15 & 3 & 0.02 & 99.9 \\
\hline 25.75 & 16 & 0 & 0 & 99.9 \\
\hline 27.36 & 17 & 2 & 0.01 & 100.0 \\
\hline
\end{tabular}

The response spectra for the ATMX car tests are shown in Figures 3 through 10. They cover the vertical and longitudinal asses for th four impact velocities of the tests. These data combine to define the response at the interface between the cargo and the cargo floor. The data for the transverse axis were so low that they were not reduced. 


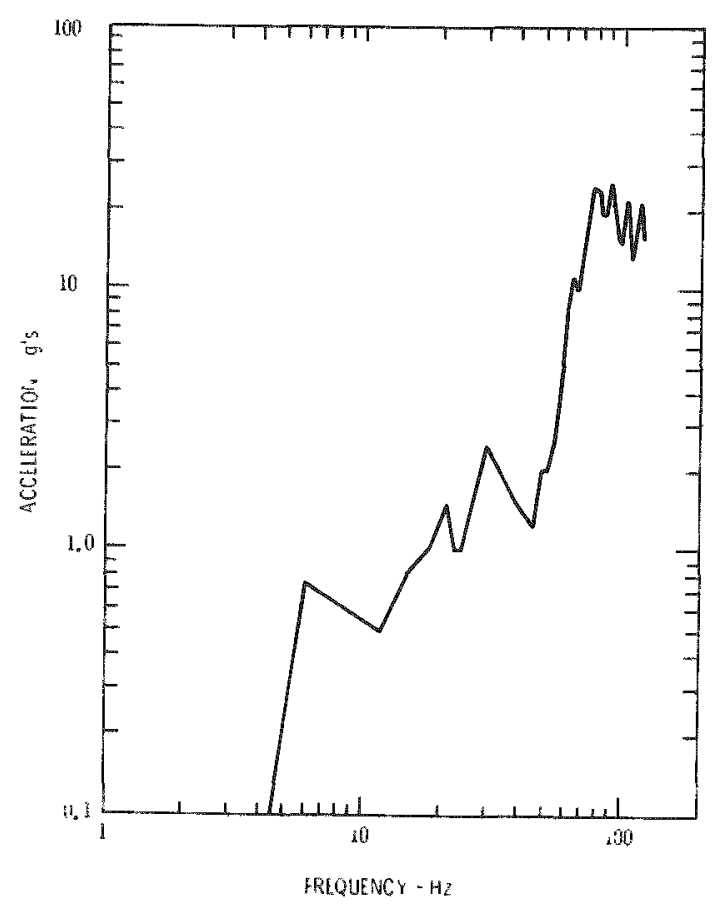

Figure 3. Railroad Coupling Shock Response Spectrum--3\% Damping -ATMX $-500=8.45 \mathrm{~km} / \mathrm{hr}(5.25 \mathrm{mph}$ I Impact - Vertical Axis

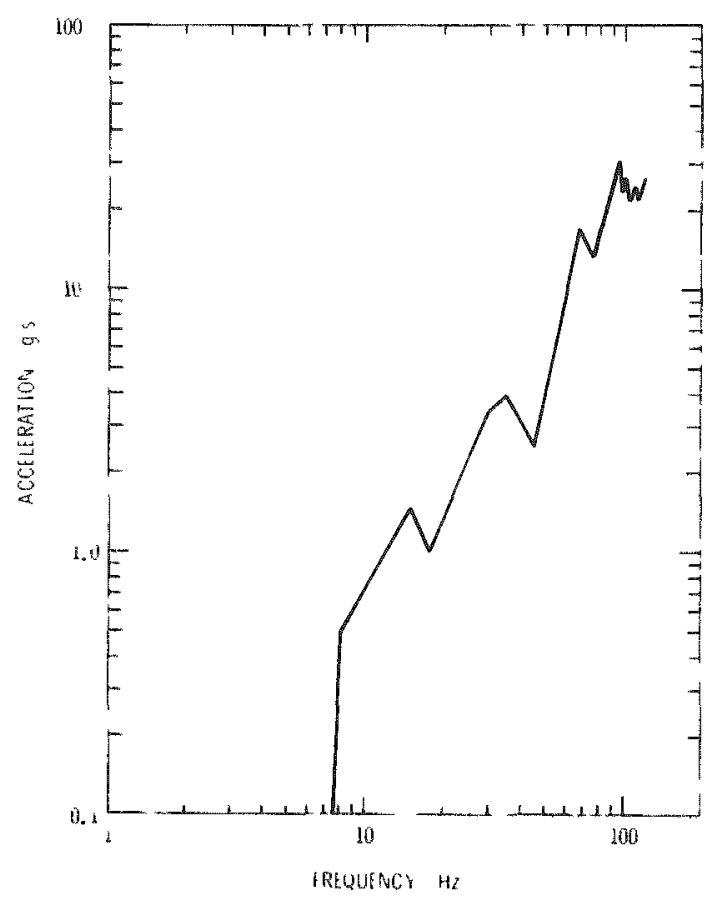

Figure 4. Railroad Coupling Shock Response Spectrum -- 3\% Damping -ATMX - 500 - $10.78 \mathrm{~km} / \mathrm{hr}(6.7 \mathrm{mph})$ Impact -- Vertical Axis 


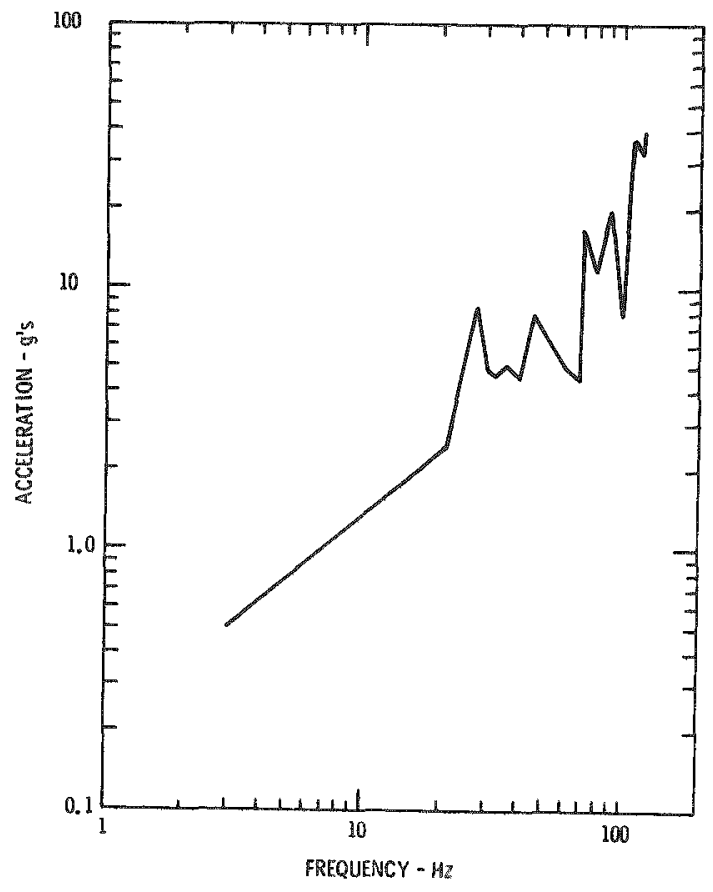

Figure 5. Railroad Coupling Shock Response Spectrum -- 3\% Damping -ATMX $-500-14.21 \mathrm{~km} / \mathrm{hr}(8.83 \mathrm{mph})$ Impact - Vertical Axis

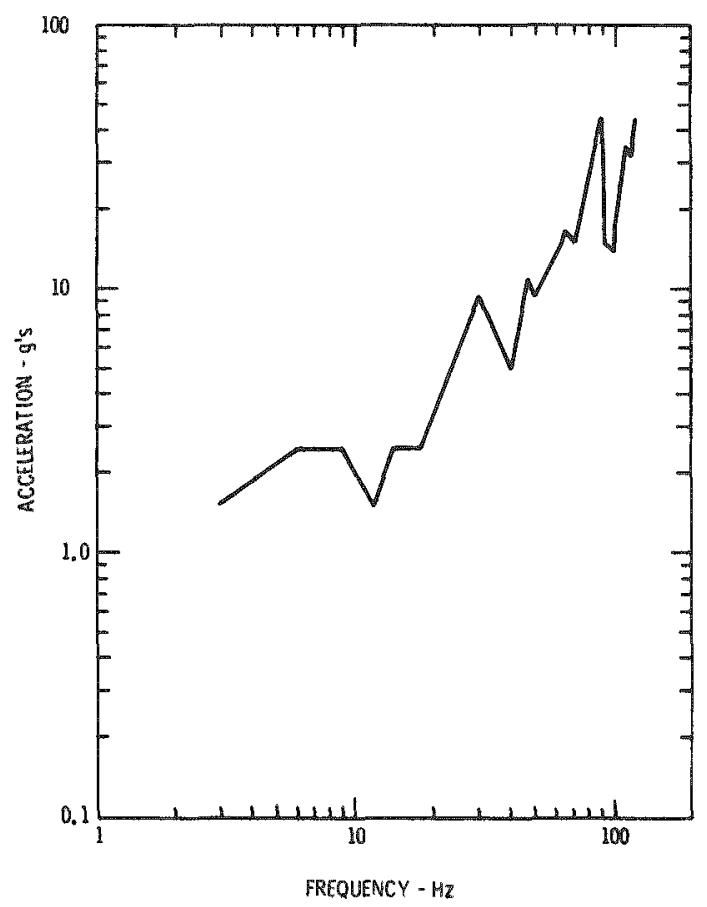

Figure 6. Railroad Coupling Shock Response Spectrum -- 38 Damping -ATMX-500 - $17.78 \mathrm{~km} / \mathrm{hr}(11.05 \mathrm{mph})$ Impact -- Vertical Axis 


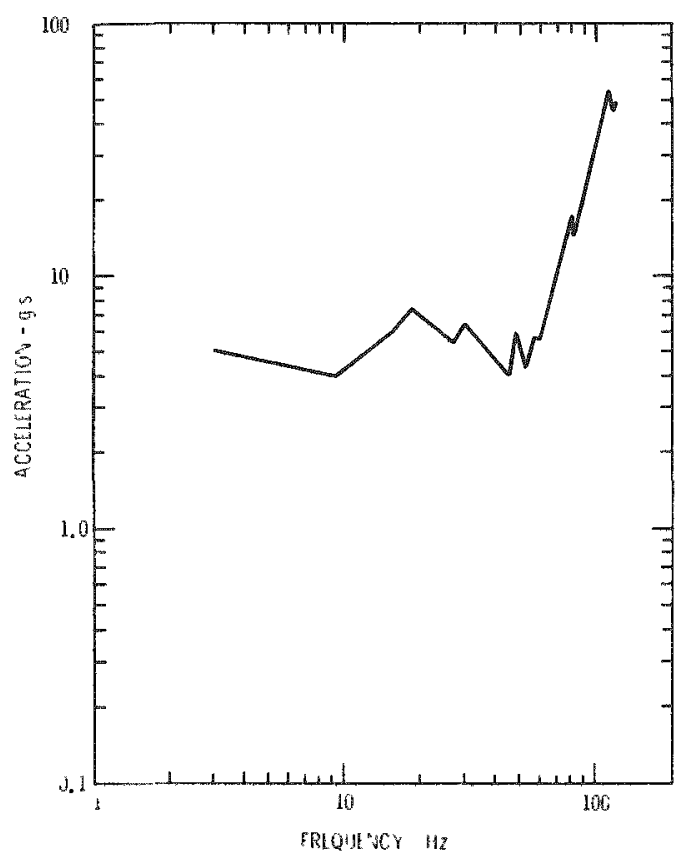

Figure 7. Railroad Coupling Shock Response Spectrum -- 3맘 Damping -ATMX-500 $=8.45 \mathrm{~km} / \mathrm{hr}(5.25 \mathrm{mph})$ Impact - Longitudinal Axis

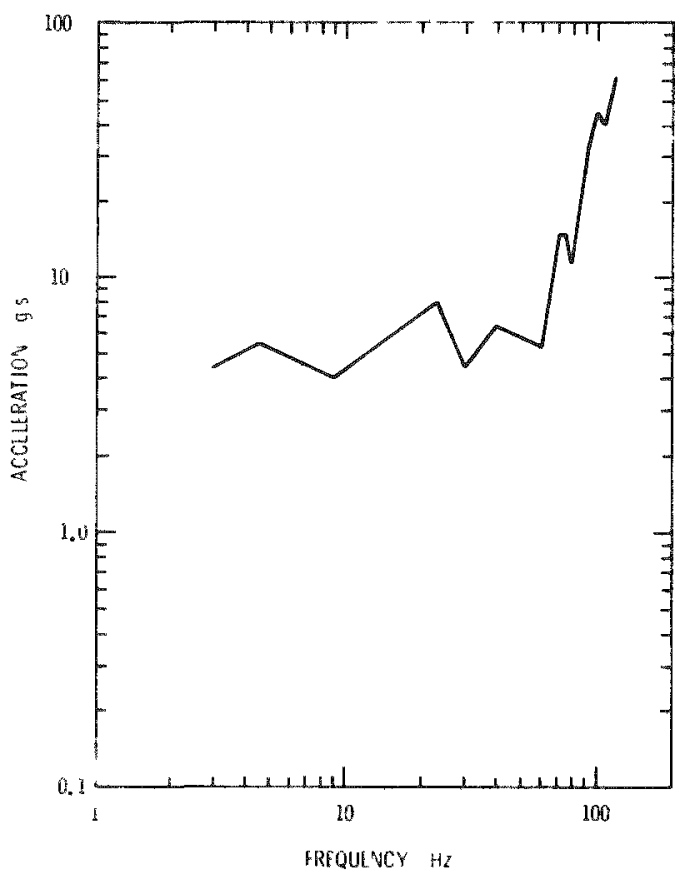

Figure 8. Railroad Coupling Shock Response Spectrum -- 3: Damping -AT $1 \mathrm{X}-500$ - $10.78 \mathrm{~km} / \mathrm{hr}(6.7 \mathrm{mph})$ Impact - Longitudinal Axis 


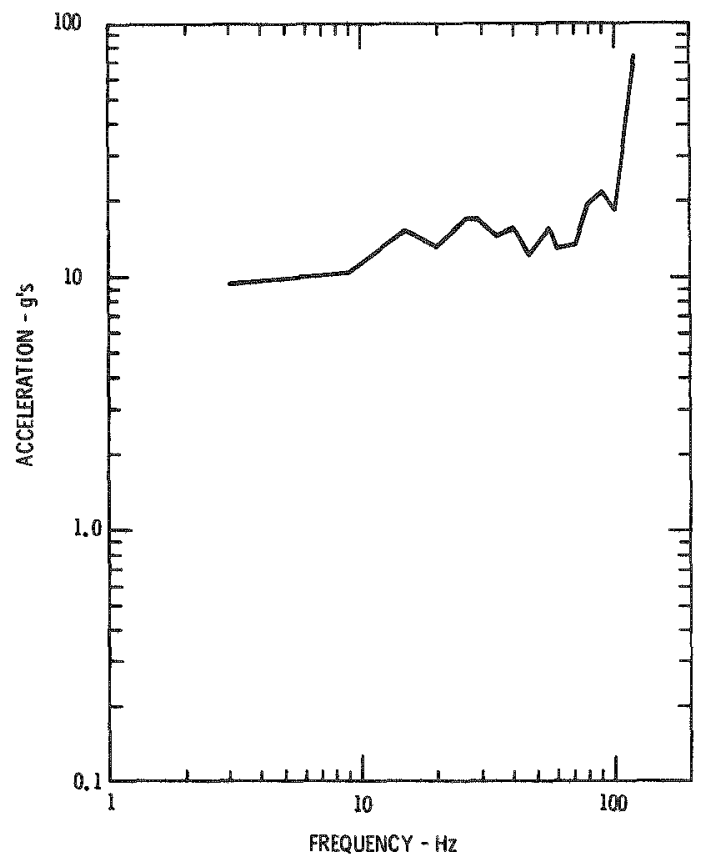

Figure 9. Railroad Coupling Shock Response Spectrum -- 3\% Damping -ATMX $-500-14.21 \mathrm{~km} / \mathrm{hr}(8.83 \mathrm{mph})$ Impact -- Longitudinal Axis

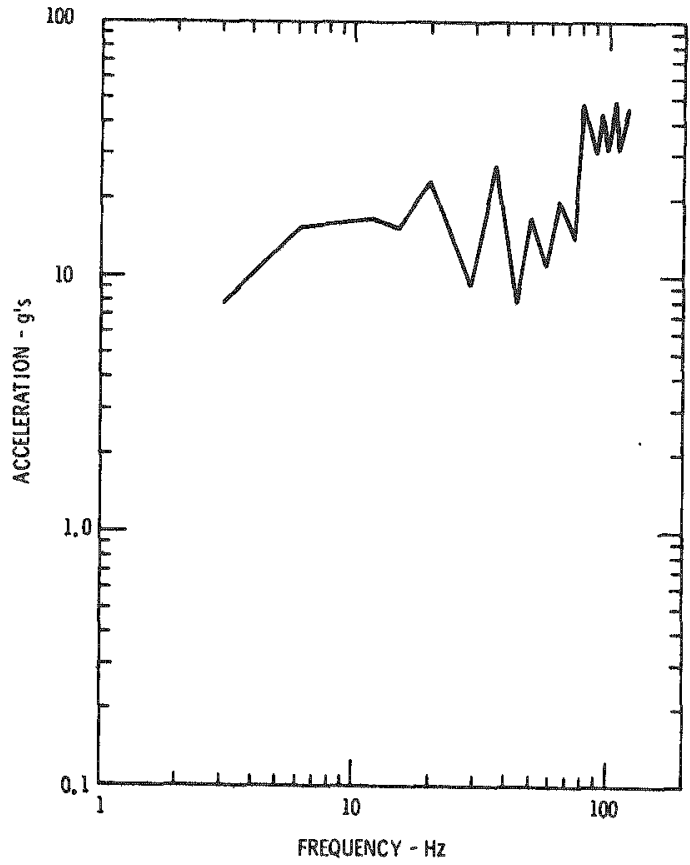

Figure 10. Railroad Coupling shock Response Spectrum -- 3\% Damping -ATMX-500 - $17.78 \mathrm{~km} / \mathrm{hr}$ (11.05 mph) Impact - Longitudinal Axis 
To simplify shock definition for evaluation of mechanical systems, it is convenient to approximate the complex inputs caused by shock with single simple pulses. In this chapter the method for deriving these simple pulses is discussed and specific pulses which produce response spectra that envelope those obtained from the tests reported in Chapter I are presented. These input pulses represent the input shock encountered in normal truck and rail transport.

\section{Method}

Simple pulses to represent input shock are derived by comparing response spectra generated from test data or analyses with the response spectrum from a single pulse. This comparison usually introduces conservatism because the response spectra from test data are enveloped by the single pulse response spectrum up to the highest frequency of interest. Several simple pulse shapes can be selected to define an input pulse. In this report, half-sine pulses are used.

An overlaying technique is used to derive the peak acceleration and pulse duration of a single half-sine input pulse to represent the complex shock pulse. In this technique, the response spectrum from the half-sine pulse is normalized by plotting the ratios of response acceleration to input acceleration against the ratio of response frequency to input frequency (Figure 11). The normalized response spectrum, computed with the same damping as the test spectrum, is then overlaid on the test spectrum so as to envelope the acceleration values of interest. The peak acceleration for the derived single pulse is taken from the point on the resulting plot where the value of the ratio of accelerations from the normalized response spectrum is one. The pulse duration is obtained in a similar manner from the inverse of the frequency at the point where the value of the ratio of frequencies is one (Figure 12). The component of velocity change which results from the exchange of energy from the simple pulse can be calculated. The velocity change, which is represented by the area under the curve of the half-sine pulse, is used to evaluate the reasonableness of the specific pulse selected for each application. 


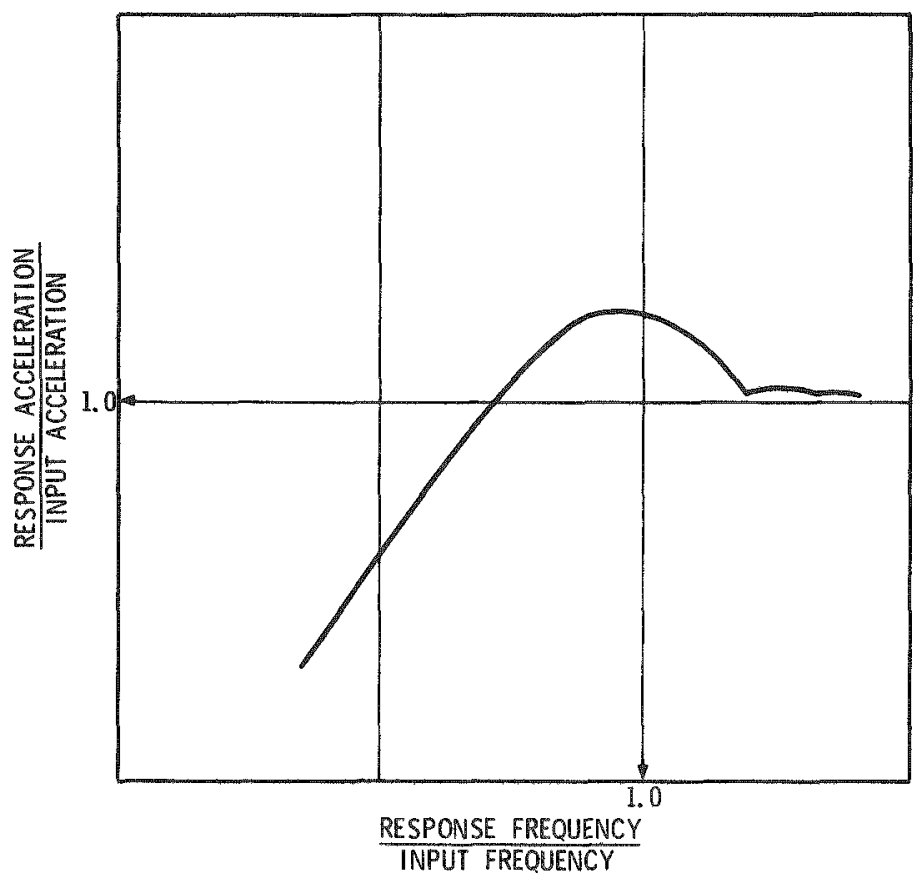

Figure 11. Normalized Single Degree of Freedom Response Spectrum Half-sine Pulse - 3\% Damping

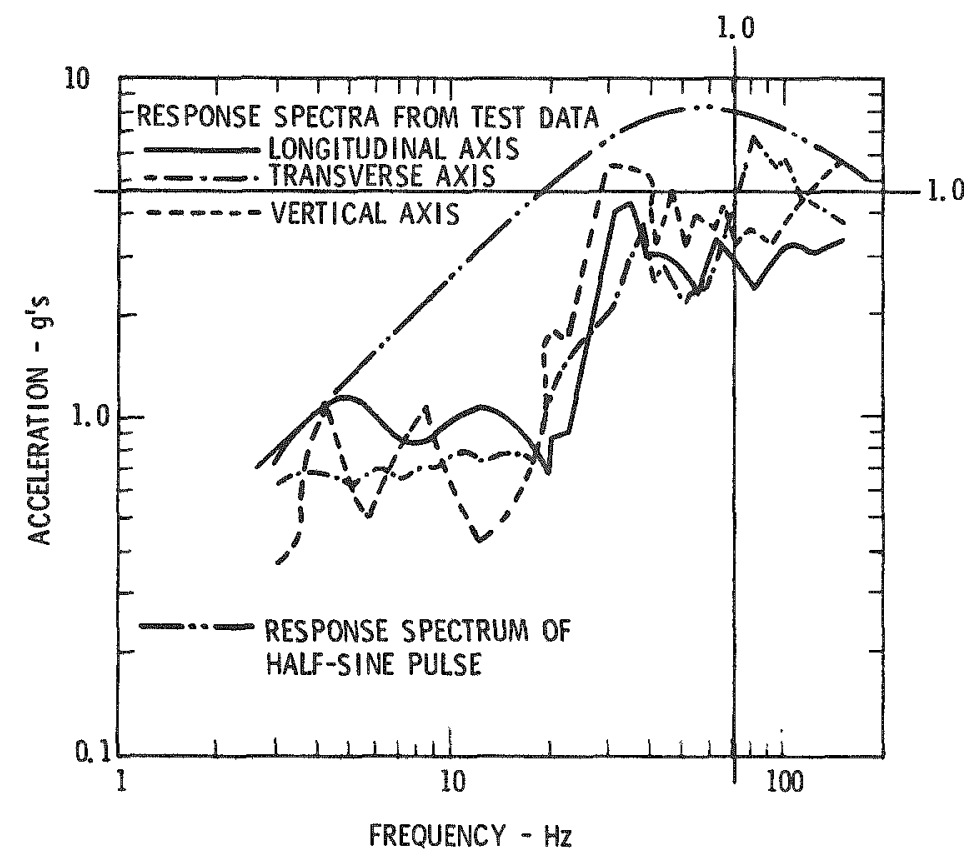

Figure 12. Test Data Response Spectra Enveloped by Simple Pulse Response Spectrum 


\section{Shock Represented by Single Half-Sine Pulses}

$m x \mathrm{Cs}$

Definitions of half-sine pulses which produce response spectra that envelope test response spectra for truck transport were developed using the technique described. The overlay fit was established for each of the three axes. The highest peak acceleration of the input pulses (7g) is in the vertical axis. The peak acceleration of input pulses in the longitudinal and transverse axes are similar in amplitude $(2.8$ and $2.3 \mathrm{~g}$ respectively). The pulse durations are those which provided the best fit for environmental data. The definitions are provided in Table IV.

TABLE IV

TRUCK/SHOCK-REPRESENTED BY SINGLE HALF-SINE PULSES

\begin{tabular}{lcccccc}
\multicolumn{1}{c}{ Axis } & $\begin{array}{c}\text { Peak } \\
\text { Acceleration }(\mathrm{g})\end{array}$ & $\frac{c}{\text { Pulse }} \begin{array}{c}\text { Duration (ms) } \\
\text { Longitudinal }\end{array}$ & 2.8 & & \multicolumn{2}{c}{$\begin{array}{c}\text { Velocity Change } \\
\text { (m/sec) }\end{array}$ (ft/sec) } \\
Transverse & 2.3 & & 19 & & .34 & 1.1 \\
Vertical & 7.0 & 77 & & 3.32 & 10.9
\end{tabular}

$\underline{\text { Rail }}$

Rail Shock Superimposed on Vibration - The response spectra obtained for rail shock which is superimposed on vibration are similar to each other in acceleration vs frequency content. Therefore, one simple input half-sine pulse having a response spectrum that envelopes the test response spectra was considered adequate for describing the shock in all three axes (Table $\mathrm{V}$ ).

Rail shock from Coupling Operations - Single half-sine pulses having response spectra which envelop the test response spectra resulting from rail coupling tests were defined. The peak accelerations and pulse durations are those which resulted from fit of a normalized response spectrum from a half-sine pulse over the spectra from test data. Test data were not reduced in the transverse axis because the response in that axis was much less than in the longitudinal and transverse axes. 
The peak accelerations of the single input half-sine pulses for the vertical axis increased from $15 \mathrm{~g}$ at $8.45 \mathrm{~km} / \mathrm{hr}(5.25 \mathrm{mph})$ coupling velocity to $26 \mathrm{~g}$ at $17.78 \mathrm{~km} / \mathrm{hr}(11.05 \mathrm{mph})$ coupling velocity. The peak accelerations of single input half-sine pulses for the longitudinal axis increased from $33 \mathrm{~g}$ at $8.45 \mathrm{~km} / \mathrm{hr}$ (5.25 mph) coupling velocity to $51 \mathrm{~g}$ at $14.21 \mathrm{~km} / \mathrm{hr}(8.83 \mathrm{mph})$ coupling velocity, but then decreased to $39 \mathrm{~g}$ at $17.78 \mathrm{~km} / \mathrm{hr}$ (11.05 mph) coupling velocity. The specific definitions of single input pulses for rail coupling shock are shown in Table $\mathrm{V}$.

TABLE V

RAIL SHOCK-REPRESENTED BY SINGLE HALF-STNE PULSES

\begin{tabular}{|c|c|c|c|c|c|c|c|}
\hline \multirow{2}{*}{ 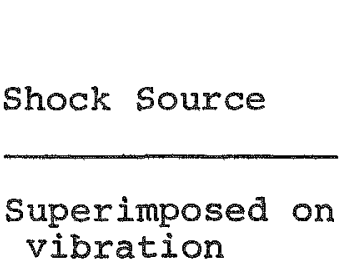 } & \multicolumn{2}{|c|}{$\begin{array}{c}\text { Coupling } \\
\text { Velocity } \\
(\mathrm{km} / \mathrm{hr}) \quad(\mathrm{mph}) \\
\end{array}$} & Axis & $\begin{array}{c}\text { Peak } \\
\text { Acceleration } \\
\text { (g) } \\
\end{array}$ & $\begin{array}{l}\text { Pulse } \\
\text { Dura- } \\
\text { tion } \\
\text { (ms) }\end{array}$ & \multicolumn{2}{|c|}{$\begin{array}{l}\text { Velocity } \\
\text { Change } \\
(\mathrm{m} / \mathrm{sec})(\mathrm{ft} / \mathrm{sec})\end{array}$} \\
\hline & NA & & Al1 & 4.7 & 14 & .40 & 1.3 \\
\hline \multirow[t]{8}{*}{$\begin{array}{l}\text { Coupling } \\
\text { Operations }\end{array}$} & 8.45 & 5.25 & Longitudina 1 & 33 & 11 & 2.26 & 7.4 \\
\hline & & & Vertical & 15 & 8 & .73 & 2.4 \\
\hline & 10.78 & 6.70 & Longitudinal & 38 & 10 & 2.35 & 7.7 \\
\hline & & & Vertical & 18 & 7 & .79 & 2.6 \\
\hline & 14.21 & 8.83 & Longitudinal & 51 & 12 & 3.78 & 12.4 \\
\hline & & & Vertical & 20 & 10 & 1.25 & 4.1 \\
\hline & 17.78 & 11.05 & Longitudinal & 39 & 18 & 4.33 & 14.2 \\
\hline & & & Vertical & 26 & 9 & 1.43 & 4.7 \\
\hline
\end{tabular}


DXNAMIC ANALYSIS OF SHOCK ENVIRONMENT

OF RAII CARS DURING COUPLING OPERATIONS

Rail coupling operations produce shock environments significantly more severe than those resulting from other truck and rail operations. Therefore, the shock environment experienced by cargo during coupling of rail cars was analyzed to identify the dependence of the environment on parameters such as cargo weight and shock attenuation couplers. Descriptions of the shock environments are presented in terms of halfsine input pulses as was done in the previous chapter for lightweight cargos. The descriptions were obtained by calculating response spectra from mathematical models derived from the structural characteristics of the systems analyzed. The analysis shows that for rail cars equipped with standard draft gear, shock environments at the cargo decrease as cargo weight increases until the coupler springs bottom out. For rail cars equipped with shock attenuation couplers, there is little variation in shock severity throughout the range of weights for which the analysis was conducted. Further, the data show that the cargo should be tied securely to the car to prevent any relative motion between the cargo and the car followed by stiff impact of the cargo against car structure.

Descriptions of the systems analyzed, mathematical models used, and the results of the analysis follow.

\section{Spring-Mass Mathematical Models}

Spring-mass models of two rail cars, a representative spent fuel cask system and the ATMX car were developed for the analyses. These models were used in a computer program to produce mathematically the shock descriptions in terms of acceleration vs time at the interface between the cargo and the carrier floor. Shock response spectra were developed from the shock description at this interface.

Spent Fuel Cask System

The spent fuel cask system was assumed to consist of a fuel cask on a skid and a rail car having a cast steel underframe. The rail car was equipped with Freightmaster Type E-15 hydraulic shock attenuation end-of-car couplers. The skid had a receptacle through which a shear structure on the rail car protrudes when the skid rests on the car floor. Clearances of $3.2 \mathrm{~mm}$ ( $1 / 8$ inch) between the shear 
structure on the car and the receptacle in the skid were assumed, as shown in Figure 13 .

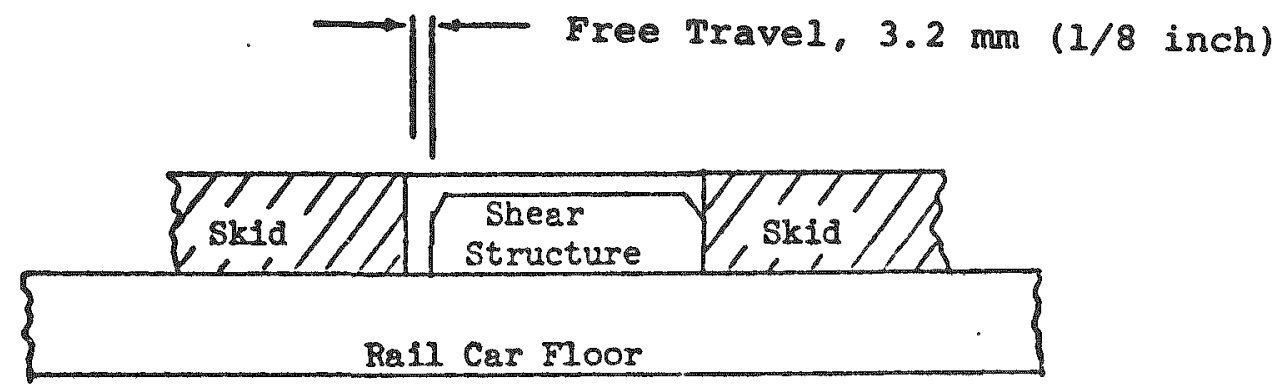

Figure 13. Shear Structure Clearance on Assumed Spent Fuel Cask System

The spent fuel cask system would be used to transport spent fuel by rail and to provide some shock attenuation during coupling. The rail car weighed $289,000 \mathrm{~N}(65,000$ pounds): the container and skid. weighed from $178,000 \mathrm{~N}(40,000$ pounds) to $890,000 \mathrm{~N}(200,000$ pounds $)$.

Mathematical Model -- The rail car model was divided into seven masses which were determined by cross bracing and other characteristics of the car structure. The masses were connected in the model by springs with rates calculated from the relationship:

$$
\mathrm{K}=\mathrm{AE} / \ell
$$

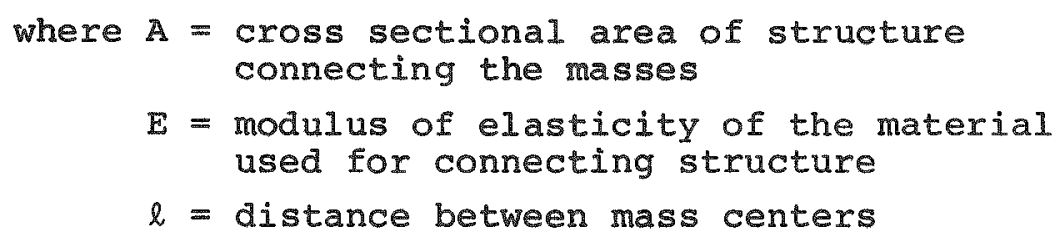

The cask was represented by a single mass located at the shear structure. The space between the shear structure and the skid was included as free travel in the spring rate for the spring between the cargo and the cargo floor. A separate mass of $801,000 \mathrm{~N}$ (180,000 pounds) was used to represent a second loaded car into which the model car was coupled. The coupler on the second car was considered to be rigid so 
that a worst case situation could be studied. The model, showing associated masses and spring rates, is diagrammed in Figure 14.
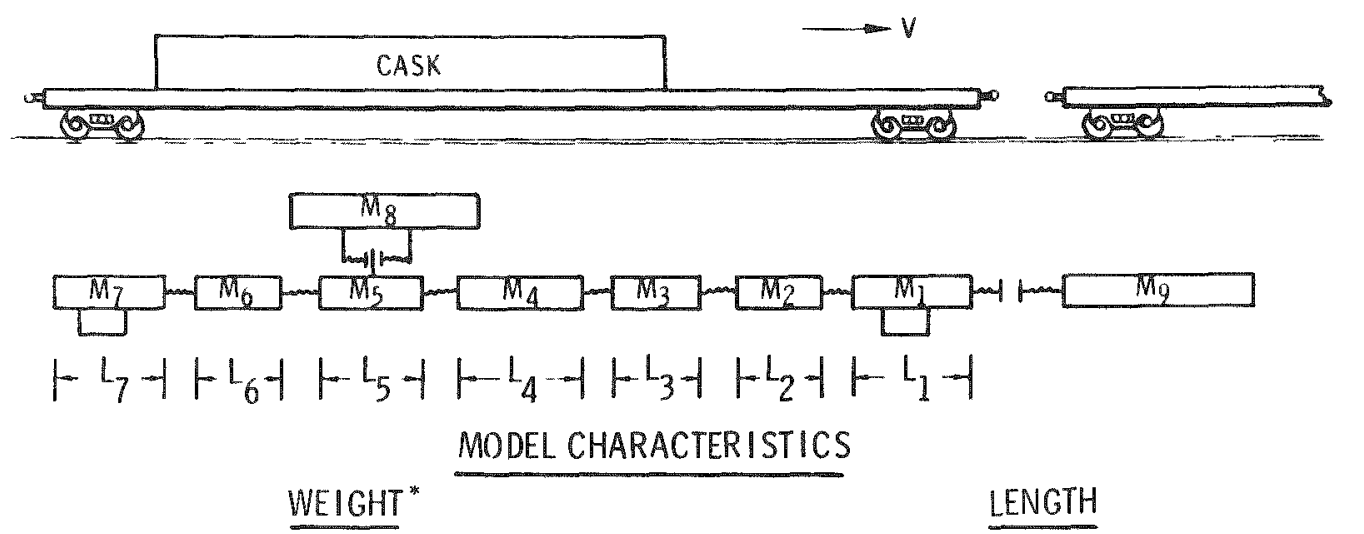

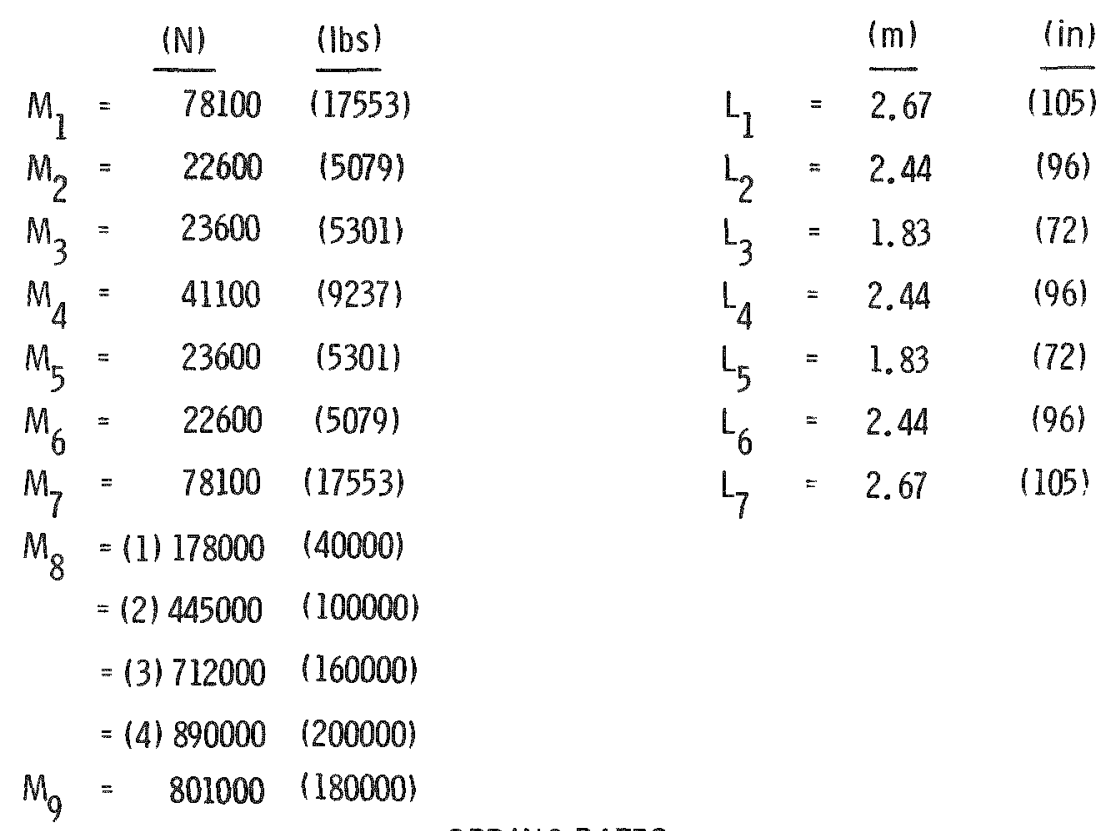

SPRING RATES

$K_{1-2}=8.98 \times 10^{9} \mathrm{~N} / \mathrm{M}\left(.5130 \times 10^{8} \mathrm{lb} / \mathrm{in}\right)$

$K_{2-3}=9.95 \times 10^{9} \mathrm{~N} / \mathrm{M}\left(.5684 \times 10^{8} \mathrm{Ib} / \mathrm{in}\right)$

$\mathrm{K}_{3-4}=16.21 \times 10^{9} \mathrm{~N} / \mathrm{M} .9256 \times 10^{8}(\mathrm{~b} / \mathrm{in})$

$K_{4-5}^{3-4}=16.21 \times 10^{9} \mathrm{~N} / \mathrm{M}\left(.9256 \times 10^{8} \mathrm{Ib} / \mathrm{in}\right)$

$\mathrm{K}_{5-6}=9.95 \times 10^{9} \mathrm{~N} / \mathrm{M}\left(.5684 \times 10^{8} \mathrm{Ib} / \mathrm{in}\right)$

$\left.K_{6-7}^{5-6}=8.98 \times 10^{9} \mathrm{~N} / \mathrm{Ml} .5130 \times 10^{8} \mathrm{lb} / \mathrm{in}\right)$

$\mathrm{K}_{1-9} @ 17.78 \mathrm{~km} / \mathrm{hr}(11.05 \mathrm{mph}) \mathrm{F}=1712570 \mathrm{~N}(385000 \mathrm{lb})$

$K_{5-8}=1.75 \times 10^{9} \mathrm{~N} / \mathrm{M} / .1000 \times 10^{8}(\mathrm{~b} / \mathrm{in})$

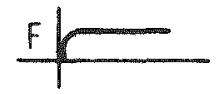

SEE PAGE 4, PAR. 3.4.1.2 OF ASTM METRIC PRACTICE GUIDE E380-72

Figure 14. Spring-Mass Model; Spent Fuel Cask System 


\section{ATMX Car}

The ATMX rail car was specially designed by Sandia Laboratories for transporting weapons. The car is built on a cast steel underframe of a flat car and is equipped with Miner RF-333 draft gear. The system analyzed included two Dow Chemical Company containers designed to transport radioactive waste material. These containers are fastened to the car floor by heavy brackets [10]. The rail car weighs $525,000 \mathrm{~N}$ ( 118,000 pounds) and the two containers weigh 451,000 N (101,300 pounds) for a total of $975,000 \mathrm{~N}(219,300$ pounds).

Mathematical Model -- The rail car model was divided into seven masses which were determined by the car structure. The masses were connected in the model by springs calculated by the relationship defined for the spent fuel cask system. The spring rate at the coupler was adjusted until the response spectrum from the model was similar to an envelope of response spectra from test data (Figure 15).

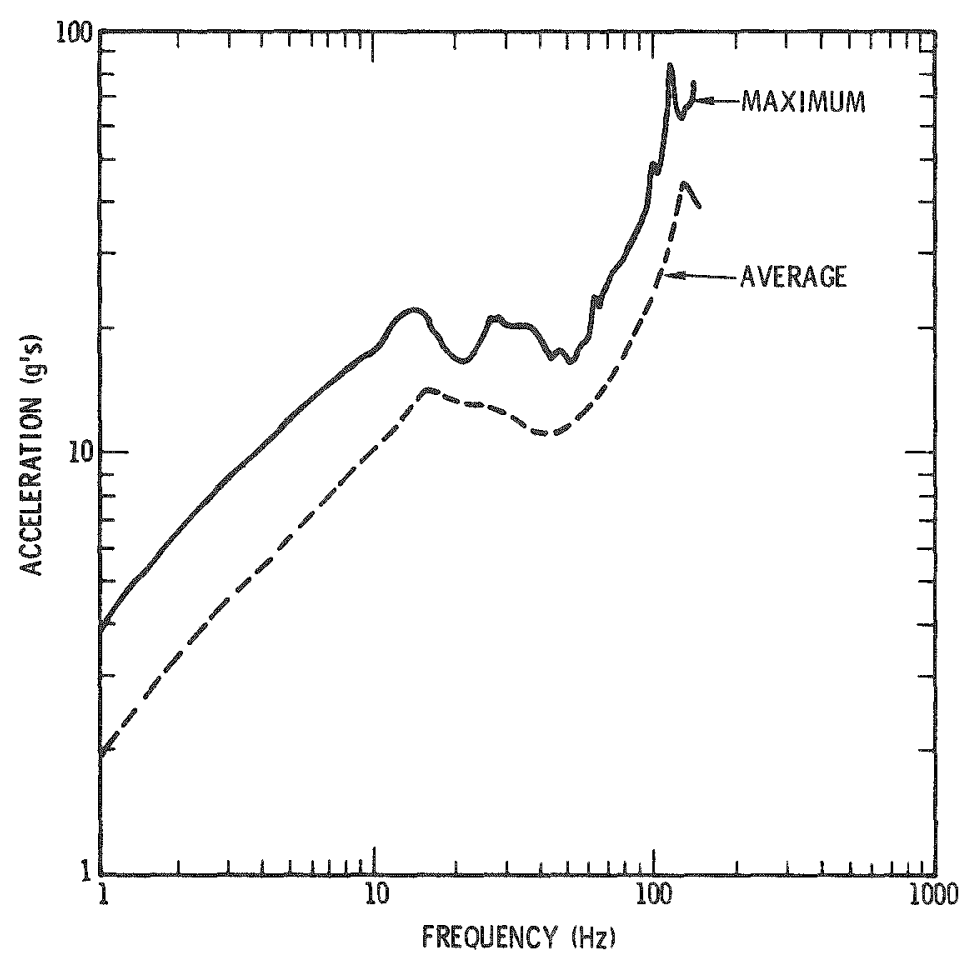

Figure 15. Shock Response Spectra - ATMX-500 and ATMX -600 Composite Spectra -38 Damping $-17.7 \mathrm{~km} / \mathrm{hr}$ (11 mph) Impact - Longitudinal Axis 
The test data were derived from 10 coupling tests of lightly loaded cars at impact speeds of $17.7 \mathrm{~km} / \mathrm{hr}$ (1I mph). The spring rate for the cargo tiedowns was estimated from an analysis of the bolts holding anti-skid brackets at the attachment to the cargo floor. Each cask was represented by a mass at the tiedown point on the car. The weights of each cask were varied from $89,000 \mathrm{~N}(20,000$ pounds) to $445,000 \mathrm{~N}$ (100,000 pounds). The second car into which the model car was coupled was assigned a mass of $890,000 \mathrm{~N}(200,000$ pounds). Again, the coupler of the second car was assumed to be rigid to present a worst case. The model, associated masses, and spring rates are shown in Figure 16.

\section{Analytical Results}

An impact velocity of $17.78 \mathrm{~km} / \mathrm{hr}$ (11.05 mph), which covers 99.8 percent of observed rail coupling impacts, was used in the analysis. Single-degree-of-freedom response spectra were produced for each of the models with the different cargo weights. These spectra are presented in the Appendix. From these spectra, simple half-sine input pulses calculated with 3 percent damping and having response spectra that envelope the spectra from the analytical models were determined.

\section{Spent Fuel Cask System}

The spent fuel cask system responds at approximately 50 to $60 \mathrm{~Hz}$. Response spectra for half-sine input pulses were fitted to the analytical response spectra through $90 \mathrm{~Hz}$. Enveloping from 0 to $90 \mathrm{~Hz}$ allows for uncertainty in the natural frequency of the system studied and permits using the half-sine input pulses for systems whose natural frequencies lie within the 0 to $90 \mathrm{~Hz}$ range.

During evaluation of the response of the spent fuel cask system, it was noted that in the 50 to $60 \mathrm{~Hz}$ frequency region, the response of the rail car structure increased as the weight of the cargo increased. The increased response was caused by the base of the skid moving against the shear structure on the car. At the end of $3.2 \mathrm{~mm}$ of free travel between the skid and the shear structure, the skid impacted the shear structure and excited the natural frequencies of the car. Therefore, as the cargo mass became greater, the force available to excite the car structure became greater. As cargo weight increases, higher peak accelerations of the simple pulses are required to envelope the response spectra of the car structure. Results of the analysis are shown in Table VI. 


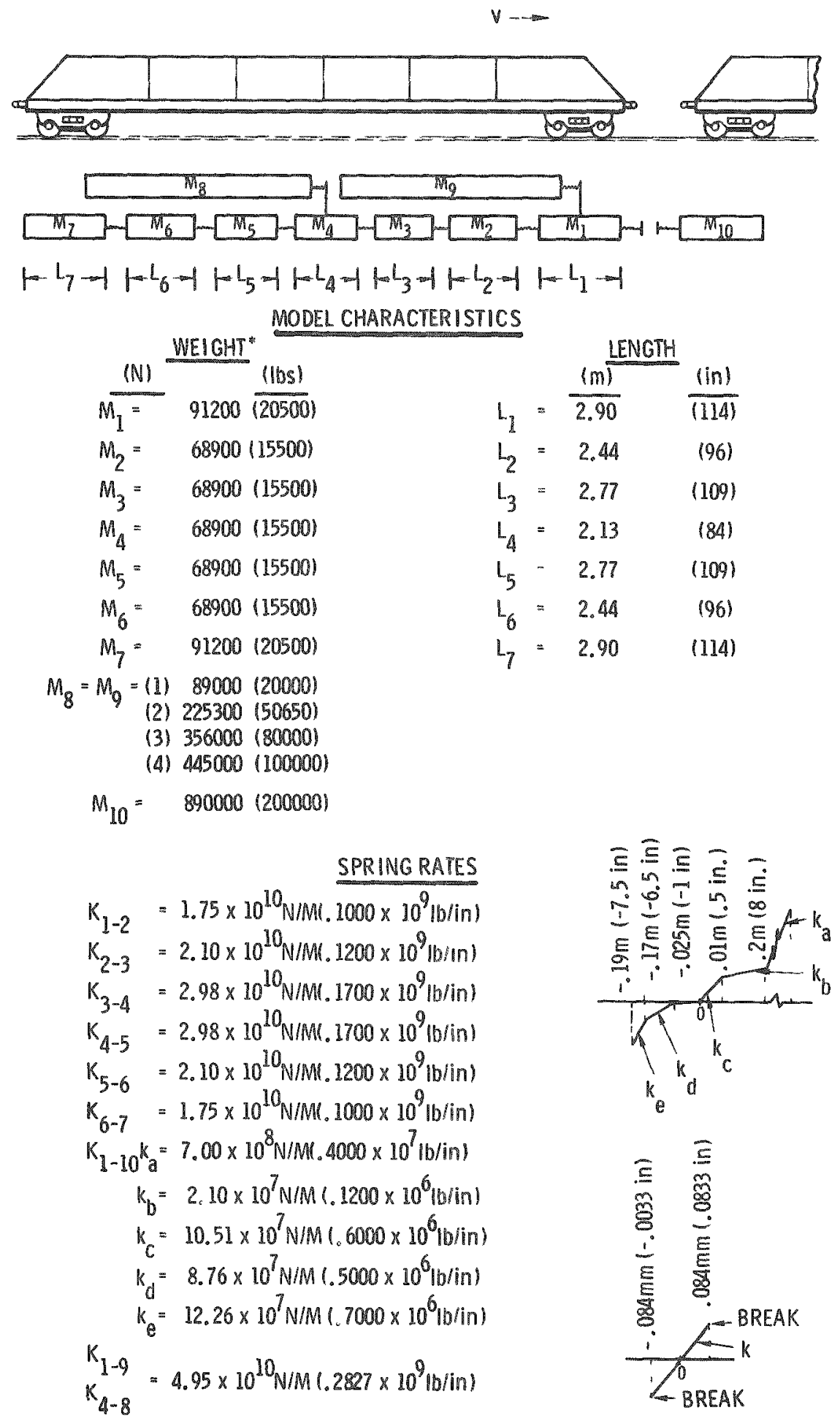

"SEE PAGE 4, PAR. 3.4.1.2 OF ASTM METRIC PRACTICE GUIDE E380-72

Figure 16. Spring-Mass Model: ATMX-600 Rail Car with Two Fuel Casks 
HALF-SINE PULSES FOR TIIE SPENT FUEI CASK SYSTEM WTTII $3.2 \mathrm{~mm}$ FREE TRAVEI SPACE

$$
(\mathbb{N})
$$

Cargo weight

$\begin{array}{lr}178,000 & 40,000 \\ 445,000 & 100,000 \\ 712,000 & 160,000 \\ 890,000 & 200,000\end{array}$

$\begin{gathered}\text { Peak } \\ \text { Acceleration } \\ \left(9^{2} s\right)\end{gathered}$
52
58
63
64

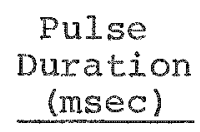

13

13

13

13
Velocity Change $(\mathrm{m} / \mathrm{sec}) \quad(\mathrm{ft} / \mathrm{sec})$

$\begin{array}{ll}4.18 & 13.7 \\ 4.66 & 15.3 \\ 5.06 & 16.6 \\ 5.15 & 16.9\end{array}$

The free travel space between the skid and the shear structure was eliminated in the model to determine the effects on the shock response if the skid were rigidy tied down. This resulted in lowering the rosponse from that of the systom with rree travel in the 50 to $60 \mathrm{hz}$ reqion but increasing the response in the 30 to $40 \mathrm{~Hz}$ region. The overall result, however, was a decrease in the peak acceleration of half-sine pulses whose response spectra envelop the response spectra developed for the modified spent fuel cask system.

The constant force vs displacement characteristic of the hyaraulic end-of-car coupler resulted in peak accelerations of the half-sine input pulses having the same amplitude over the range of weights for which the study was conducted. The pulse durations of the input pulses were changed from those of the preceding model to provide an equally good fit without introducing additional conservatism and to maintain reasonable velocity changes. The results are shown in Table VII.

TABLE' VII

HALF-SINE PULSES FOR THE SPENT FUEL CASK SYSTEM WITI CASK TIED DOWN

\begin{tabular}{|c|c|c|c|c|c|}
\hline (N) $^{\text {Cargo }}$ & Weight (1bs) & $\begin{array}{c}\text { Peak } \\
\text { Acceleration } \\
\left(g^{8} s\right) \\
\end{array}$ & $\begin{array}{c}\text { Pulse } \\
\text { Duration } \\
\text { (msec) }\end{array}$ & $\begin{array}{l}\text { Velocity } \\
(\mathrm{m} / \mathrm{sec})\end{array}$ & $\begin{array}{l}\text { Change } \\
(\mathrm{ft} / \mathrm{sec})\end{array}$ \\
\hline 178,000 & 40,000 & 49 & 14 & 4.24 & 13.9 \\
\hline 445,000 & 100,000 & 49 & 14 & 4.24 & 13.9 \\
\hline 712,000 & 160,000 & 49 & 14 & 4.24 & 13.9 \\
\hline 890,000 & 200,000 & 49 & 14 & 4.24 & 13.9 \\
\hline
\end{tabular}


A comparison of the peak acceleration of the half-sine input pulses for the spent fuel cask system with and without the free space between the skid and the shear structure is shown in Figure 17.

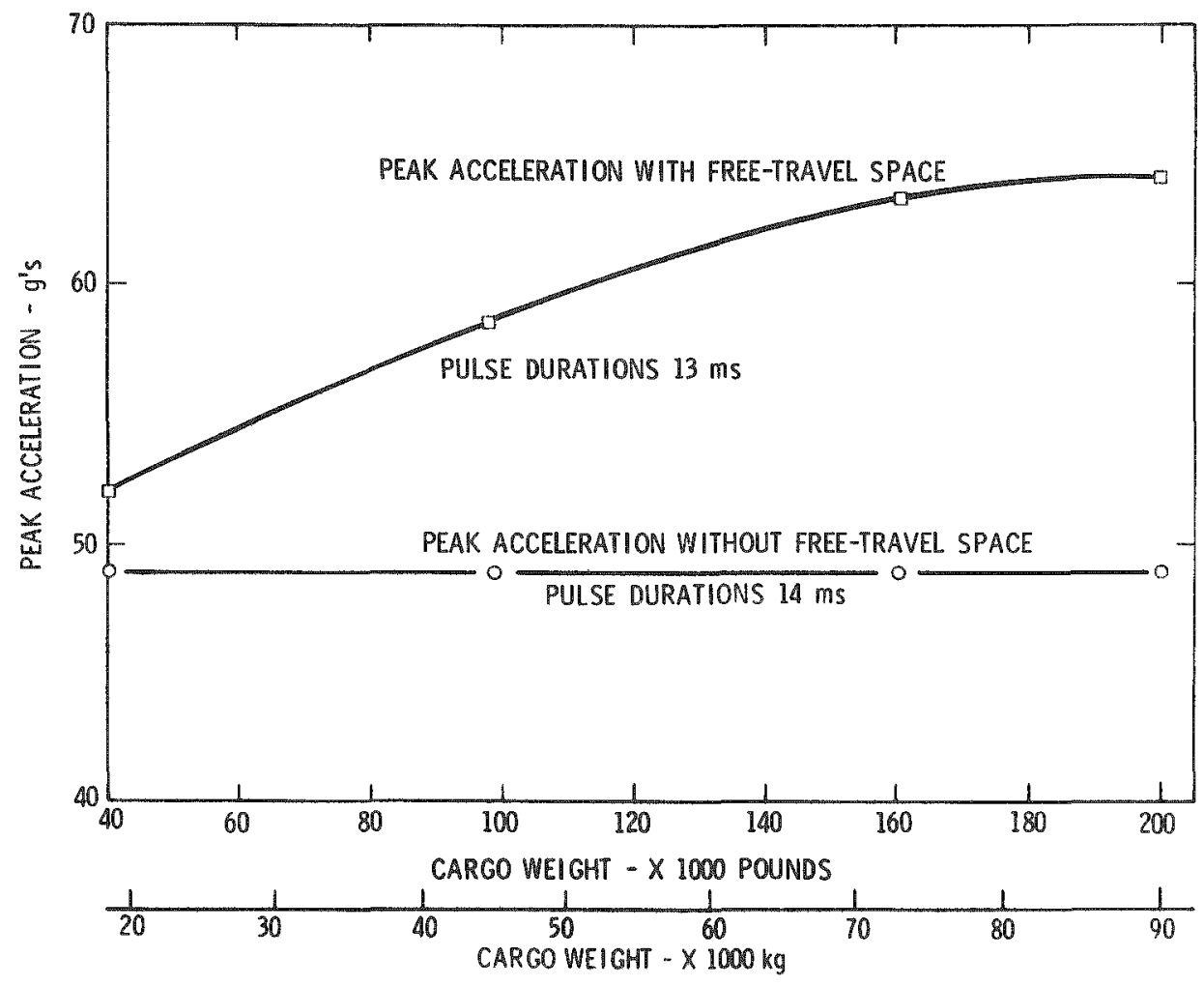

Figure 17. Peak Acceleration and Pulse Duration Half-Sine Pulses - Spent Fuel Cask System Longitudinal Axis

\section{ATMX Car}

The ATMX car tiedown structure responds at approximately $100 \mathrm{~Hz}$. Again, response spectra for half-sine input pulses were fitted to analytical response spectra to cover higher frequencies. In this case fitting the half-sine response spectra at $100 \mathrm{~Hz}$ resulted in the analytical response spectra being enveloped to $200 \mathrm{~Hz}$. Enveloping to $200 \mathrm{~Hz}$ allows for uncertainty in the natural frequency of the ATMX system studied and permits using these half-sine pulses for systems whose natural frequencies lie within the 0 to $200 \mathrm{~Hz}$ frequency range. The peak accelerations of the simple input pulses decreased as cargo weight increased up to $712,000 \mathrm{~N}(160,000$ pounds) and then increased at $890,000 \mathrm{~N}(200,000$ pounds) cargo weight. The higher peak acceleram tions of the input pulses which are required to envelop the response spectra of the lighter cargo analytical response spectra result from 
more violent reaction of the smaller masses to the springs in the spring-mass model. The high peak acceleration at $890,000 N: 200,000$ pound) cargo weight results from bottoming out of the coupler spring which creates greater excitation in the tie-down structure. The results are shown in Table VIII.

TABIE VIII HALF-SINE PULSES FOR ATMX SYSTEM
WITH STANDARD DRAFT GEAR

\begin{tabular}{|c|c|c|c|c|c|}
\hline $\begin{array}{r}\text { Cargo } \\
(\mathrm{N}) \\
\end{array}$ & $\begin{array}{l}\text { Woight } \\
\text { (Ibs) }\end{array}$ & $\begin{array}{c}\text { Peak } \\
\text { Acceleration } \\
\left(g^{\prime} s\right)\end{array}$ & $\begin{array}{l}\text { Pulse } \\
\text { Duration } \\
\text { (msec) } \\
\end{array}$ & $\begin{array}{c}\text { Velocity } \\
(\mathrm{m} / \mathrm{sec})\end{array}$ & $\begin{array}{l}\text { Change } \\
\text { (ft/sec) }\end{array}$ \\
\hline 178,000 & 40,000 & 75 & 10 & 4.63 & 15.2 \\
\hline 451,000 & 101,300 & 55 & 10 & 3.41 & 11.2 \\
\hline 712,000 & 160,000 & 45 & 10 & 2.77 & 9.1 \\
\hline 890,000 & 200,000 & 55 & 10 & 3.41 & 11.2 \\
\hline
\end{tabular}

The model of the ATMX car was revised to include the characteristics of the .38 metre (15-inch) hydraulic shock attentuation end-of-car couplers which are a part of the spent fuel cask system. This was done to determine the effects on the cargo if the ATMX car was equipped with these devices. As on the spent fuel cask system, the analytical response spectra were about constant over the range of weights for which the study was conducted (Table IX). However, the magnitude of the peak acceleration was higher for the ATMX car because the end-ofcar coupler and tiedown stiffness were not compatible.

TABLE IX

HALF-SINE PULSES FOR ATMX SYSTEM WITH . 38 METRE (15-INCH) HYDRAULIC END-OF-CAR COUPLERS

\begin{tabular}{|c|c|c|c|c|c|}
\hline $\begin{array}{l}\text { Cargo } \\
(\mathrm{N})\end{array}$ & $\begin{array}{r}\text { Weight } \\
\text { (1bs) }\end{array}$ & $\begin{array}{c}\text { Peak } \\
\text { Acceleration } \\
\left(g^{\prime} s\right) \\
\end{array}$ & $\begin{array}{c}\text { Pulse } \\
\text { Duration } \\
\text { (msec) } \\
\end{array}$ & $\begin{array}{c}\text { Velocity } \\
\text { (m/sec) }\end{array}$ & $\begin{array}{l}\text { Change } \\
(\mathrm{ft} / \mathrm{sec})\end{array}$ \\
\hline 178,000 & 40,000 & 80 & 10 & 4.94 & 16.2 \\
\hline 451,000 & 101300 & 80 & 10 & 4.94 & 16.2 \\
\hline 712,000 & 160,000 & 80 & 10 & 4.94 & 16.2 \\
\hline 890,000 & 200,000 & 80 & 10 & 4.94 & 16.2 \\
\hline
\end{tabular}


A comparison of the half-sine input pulses for the ATMX car equipped with standard draft gear and .38 metre (15-inch) hydraulic end-of-car couplers is shown in Figure 18 .

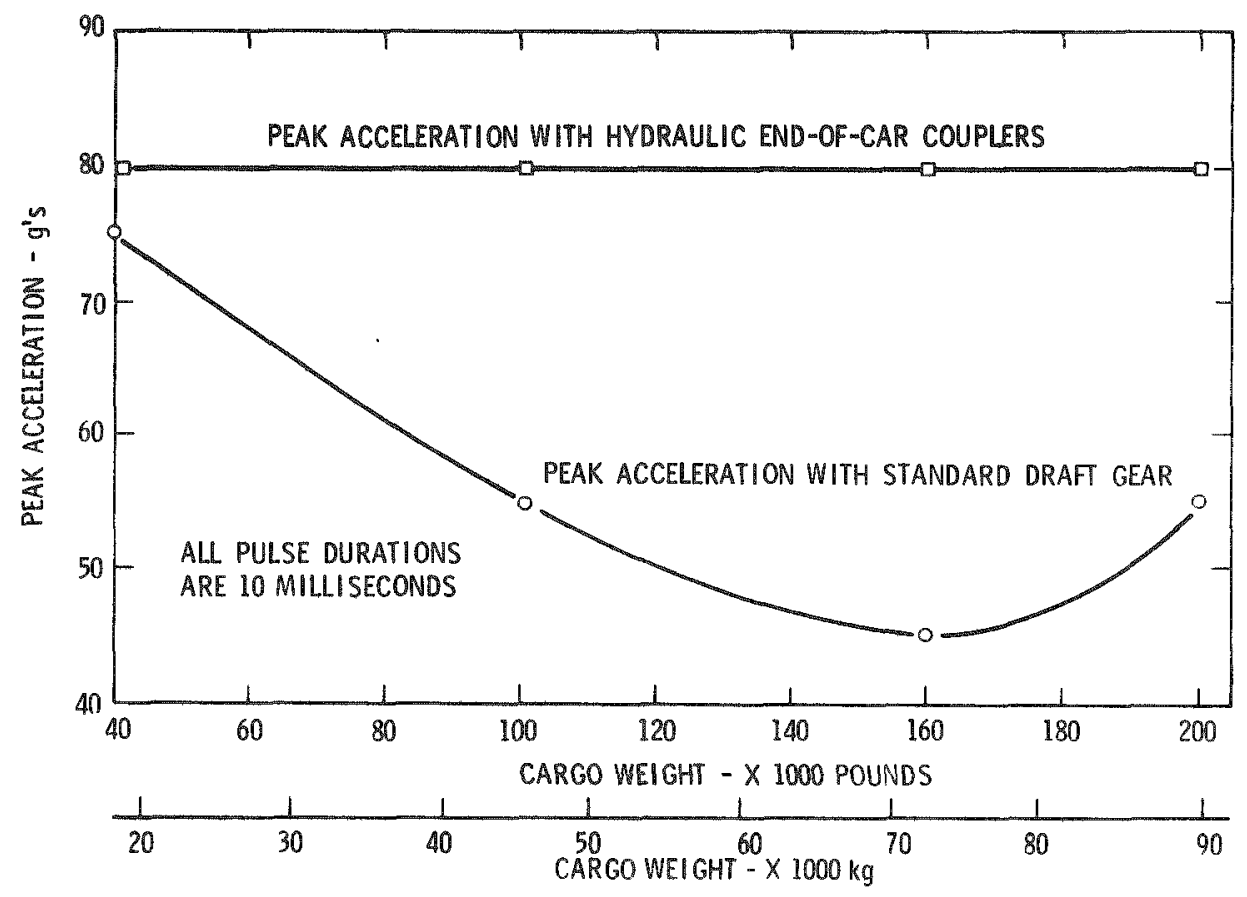

Figure 18. Peak Acceleration and Pulse Duration Half-Sine Pulses - ATMX System Longitudinal Axis

The curves in Figure 18 show that, if improperly matched end-ofcar couplers and tiedown stiffnesses are used, the peak accelerations of half-sine pulses which envelop the response spectra are higher than those required to envelop the spectra for standard draft gear. However, when one compares the response spectra, which are shown in the Appendix (for example: Fig. A-5 \& A-13), for the spent fuel system (cargo tied down) with the ATMX car using the identical endof-car couplers and resulting spring rates, one finds that response accelerations for the spent fuel cask system are higher in most frequencies. Yet the peak accelerations of the simple input pulses are higher for the ATMX car. These higher peak accelerations are caused by the need to envelop the ATMX response spectra to $100 \mathrm{~Hz}$ while the spectra for the spent fuel cask system is enveloped to only $60 \mathrm{~Hz}$. If the ATMX tiedown system stifiness was reduced to $75 \mathrm{~Hz}$, the 
peak accelerations of simple pulses to envelop the response spectra with the hydraulic end-of-car coupler would be a constant $49 \mathrm{~g}$ just as the tied down spent fuel cask system. If the system stiffness can be reduced further, the peak accelerations of the simple pulses would be lower. 
Conclusions

Based on analytical studies conducted for this chapter the following conclusions can be drawn for $17.78 \mathrm{~km} / \mathrm{hr}$ (11.05 mph) coupling velocities:

(1) Containers should be tied securely to the rail car to avoid any relative motion between the cargo and the car followed by stiff impact of the cargo against car structure.

(2) For rail cars equipped with standard draft gear, cargo response decreased as weight increased up to the point where the coupler springs bottom out. For the conventional ATMX rail car, $712,000 \mathrm{~N}(160,000$ pounds $)$ is the cargo weight which permits the most efficient use of the spring system employed in the couplers. Iighter cargo weights appear to be driven more violently because of stiffness. Heavier cargo resulted in bottoming of the couplex springs. This bottoming caused increased response in the tie-down structure.

(3) If the cargo is tied securely to the rail car and shock attenuating couplers are used, cargo weight has little effect on the cargo response to coupling impacts. Matching the end-of-car coupler to the cargo weight as well as tuning the tie-down stiffness would decrease the peak acceleration level to the cargo.

(4) Each transportation system, consisting of a rail car, container, and tie-down structure, form a dynamic system which is best studied and analyzed on an individual basis. Results from general studies of the type presented in this report cannot treat all of the designdependent detail that will vary from one system to another. The analytical procedures employed here are applicable, however, and may be useful for more precise investigations of specific systems. 


\section{References}

1. Summary of Data from Truck shipment of a Uranium Cask from Oak Ridge, Tennessee to Paducah, Kentucky. Data Bank Entry No. 1313.

2. Transportation Dynamic Environment Summary, January 1973, Data Bank Entry Number A1354, is a summary which resulted from assembling, collating, and interpreting all the transportation vibration and shock data placed in the data bank from its inception in 1960 through January 1973.

3. Paper presented at 16th Annual Technical Meeting, Institute of Environmental Sciences; April 1970. "Report on Rail Shipment of a Cask between Paducah, Kentucky and Oak Ridge, Tennessee." Data Bank Entry Number 1320 .

4. Report No, FRA-RT-70-26, DOT Contract No. DOT-FR-9-0038, dated August 1970, Robert $W$. Luebke, Chesapeake and Ohio Railway/ Baltimore and Ohio Railroad. Data Bank Entry 1328.

5. Extraction from Shock and Vibration Bulletin 33, Part II, 1964, L. W. Lahood, Raytheon. Data Bank Entry Number 289.

6. Extraction from Observed Switching Speeds Empty and Loaded Cars Erie R.E. Co., Hammond Yard; Indiana Harbor Belt R.R. Co., Gibson Yard; Illinois R.R., Markham Yard. Data Bank Entry No. 286.

7. Extraction from the Railroad Environment, Technical Research Department, New York Central Railroad, 1960. Data Bank Entry Number 1118.

8. Extraction from Shock and Vibration Handbook, Volume 3, 1961, occurrence of Rail Switching Shock. Data Bank Entry Number 287.

9. Specifications for Design, Fabrication and Construction of Freight Cars, Association of American Railroads, Chicago, Ill., Sept. 1, 1964 .

10. ATMX-600 Railcar, A New Concept in Radioactive Waste Shipments, Frank E. Adcock, Proceedings Third International Symposium Packaging and Transportation of Radioactive Materials, August 1620, 1971, 71501 (Vol. 1), Richland, Washington Conference. 


\section{APPENDIX}

COMPUTER-GENERATED RESPONSE SPECTRA

Response spectra generated by analysis of the spring-mass models discussed in Chapter III are presented in this Appendix. They result from analysis of response of the models to shock caused by rail coupling. The impact velocity used in the analysis was $17.78 \mathrm{~km} / \mathrm{hr}(11.05 \mathrm{mph})$. Cargo weight was varied from 178,000 to $890,000 \mathrm{~N}(40,000$ to 200,000 pounds $)$. 


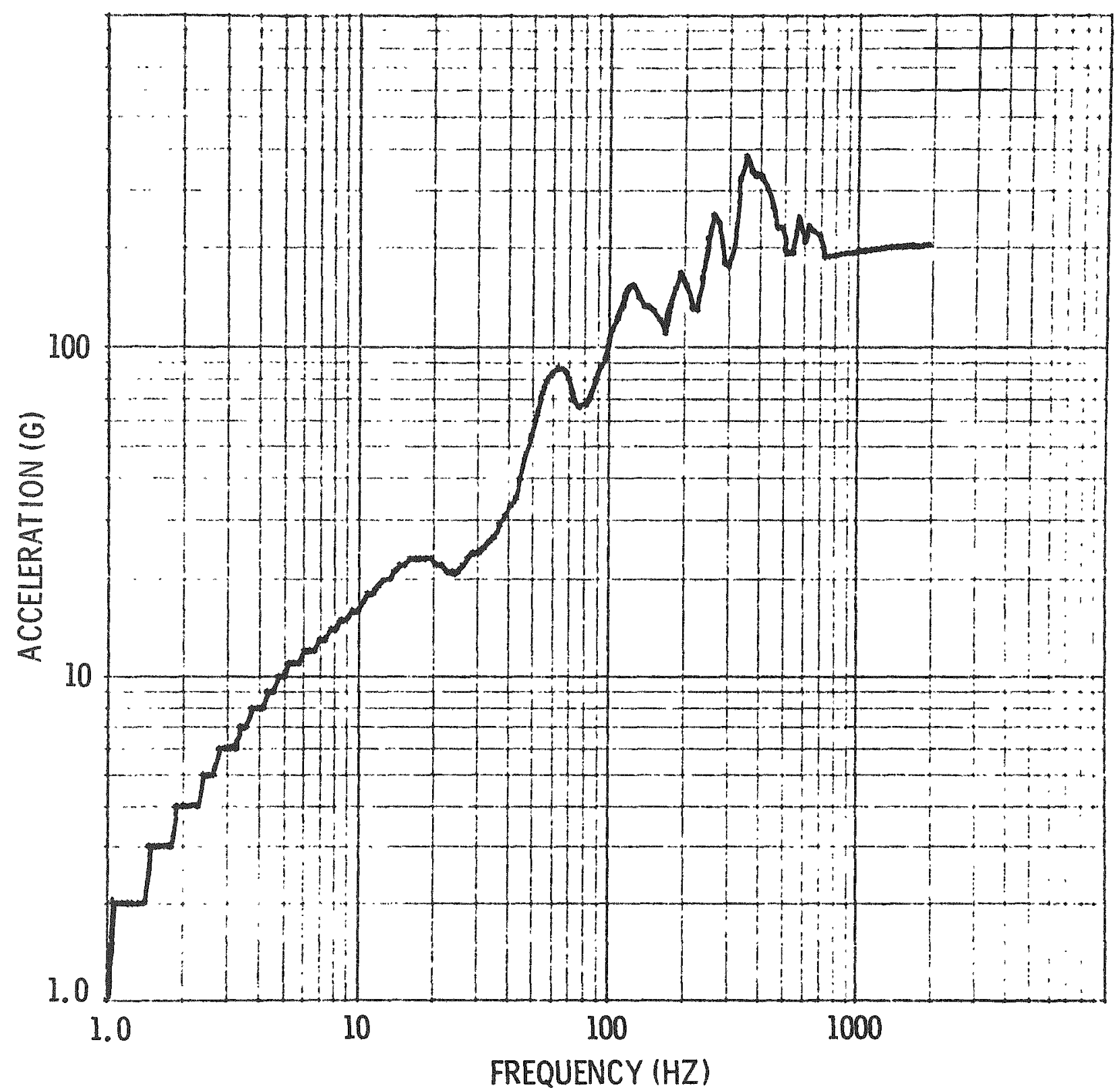

Figure A-1. Response Spectrum Analytical Results

Spent Fuel Cask System with $3.2 \mathrm{~mm}$ (1/8 inch) Spacing, $178,000 \mathrm{~N}(40,000$ pound)

Cargo, $17.78 \mathrm{~km} / \mathrm{hr}$ (11.05 mph) Impact

Velocity, 3 percent Damping, Longitudinal Axis 


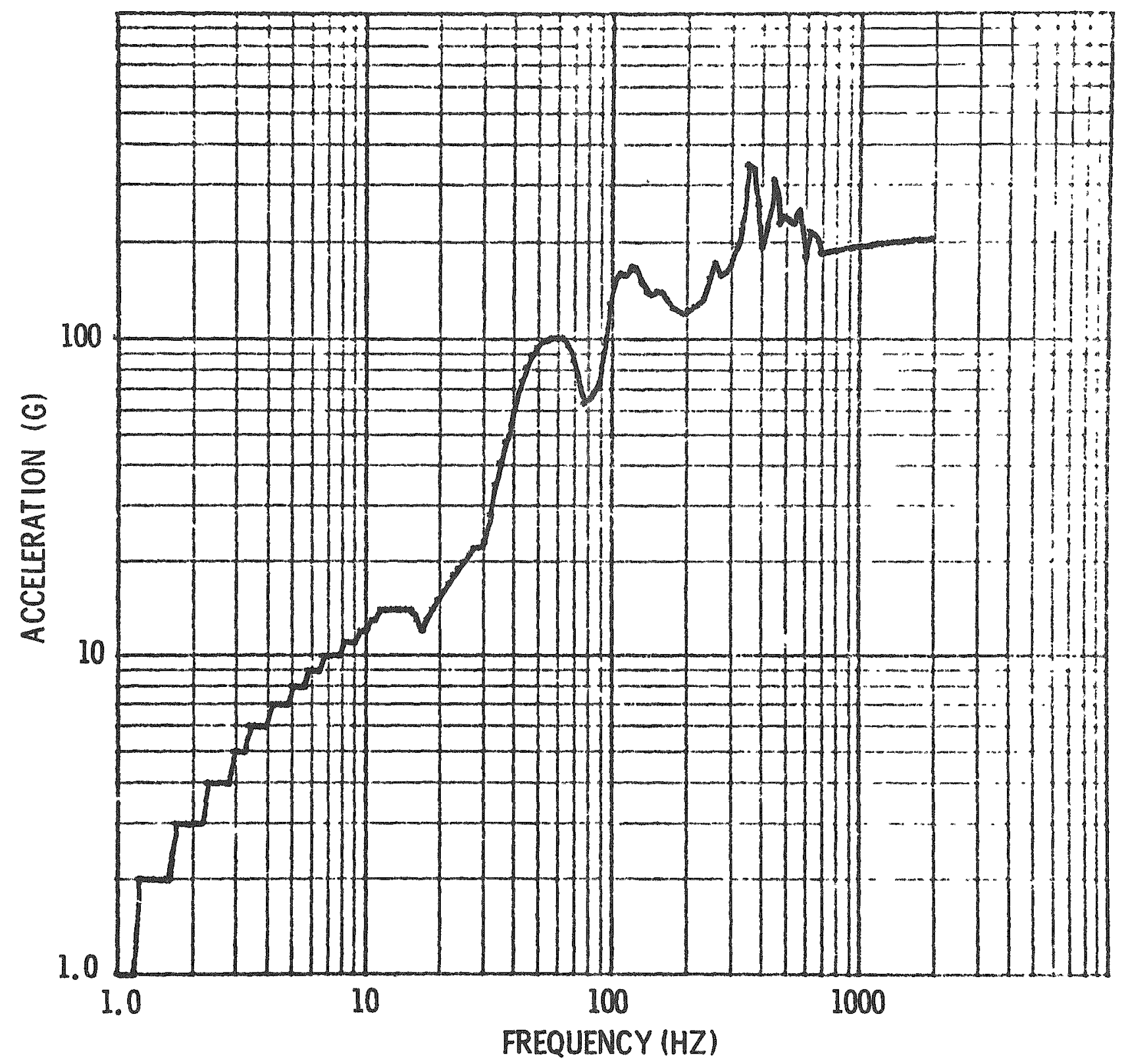

Figure A-2. Response Spectrum
Analytical Results

Spent Fuel Cask system with $3.2 \mathrm{~mm}(1 / 8$

inch) spacing, 445,000 N (100,000 pound)

Cargo, $17.78 \mathrm{~km} / \mathrm{hr}$ (11.05 mph) Impact

Velocity, 3 percent Damping, Longitudinal

Axis 


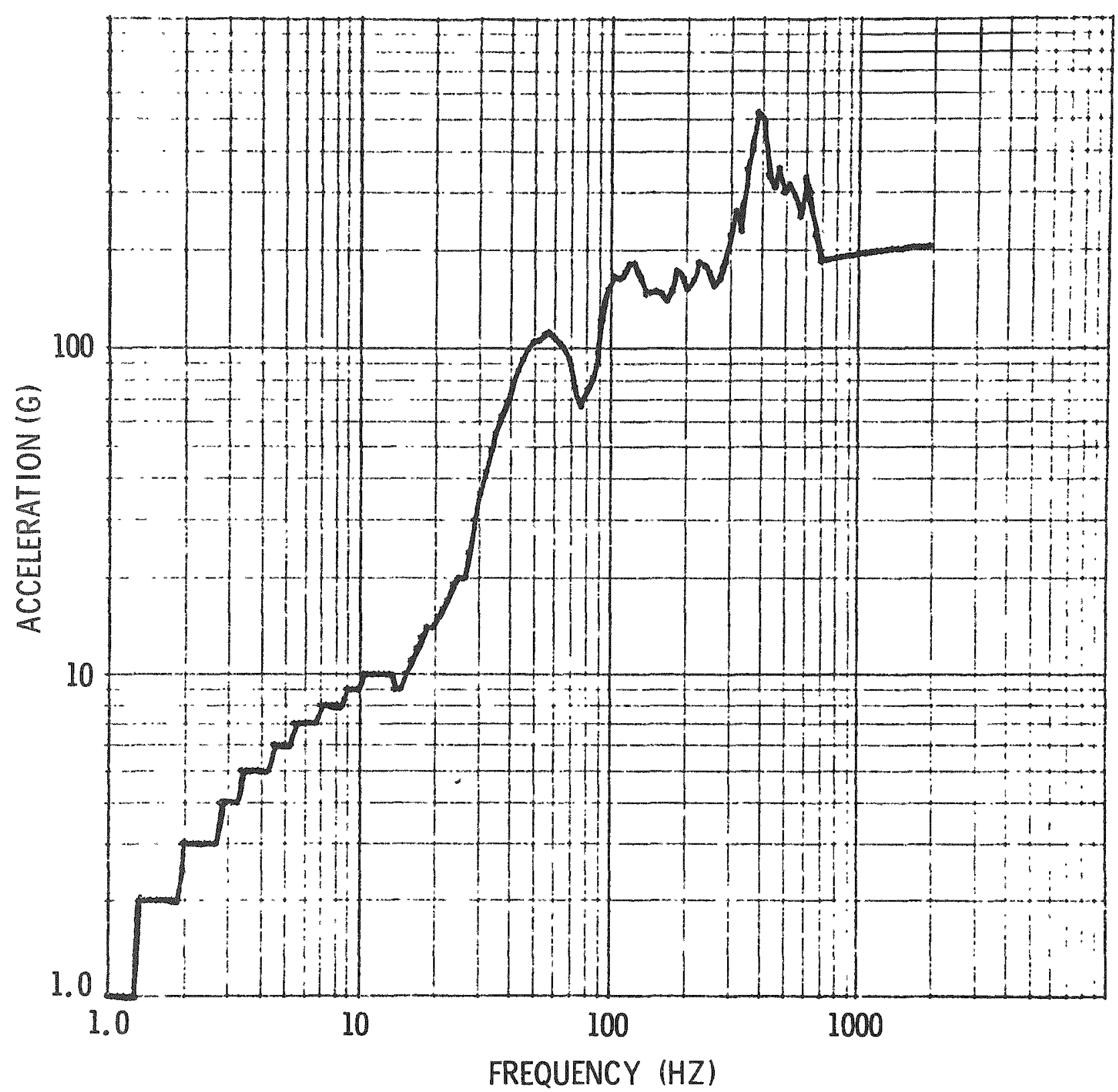

Figure A-3. Response Spectrum Analytical Results

Spent Fuel Cask System with $3.2 \mathrm{~mm}(1 / 8$ inch) spacing, $712,000 \mathrm{~N}(160,000$ pound) Cargo, $17.78 \mathrm{~km} / \mathrm{hr}$ (11.05 mph) Impact Velocity, 3 percent Damping, Longitudinal Axis 


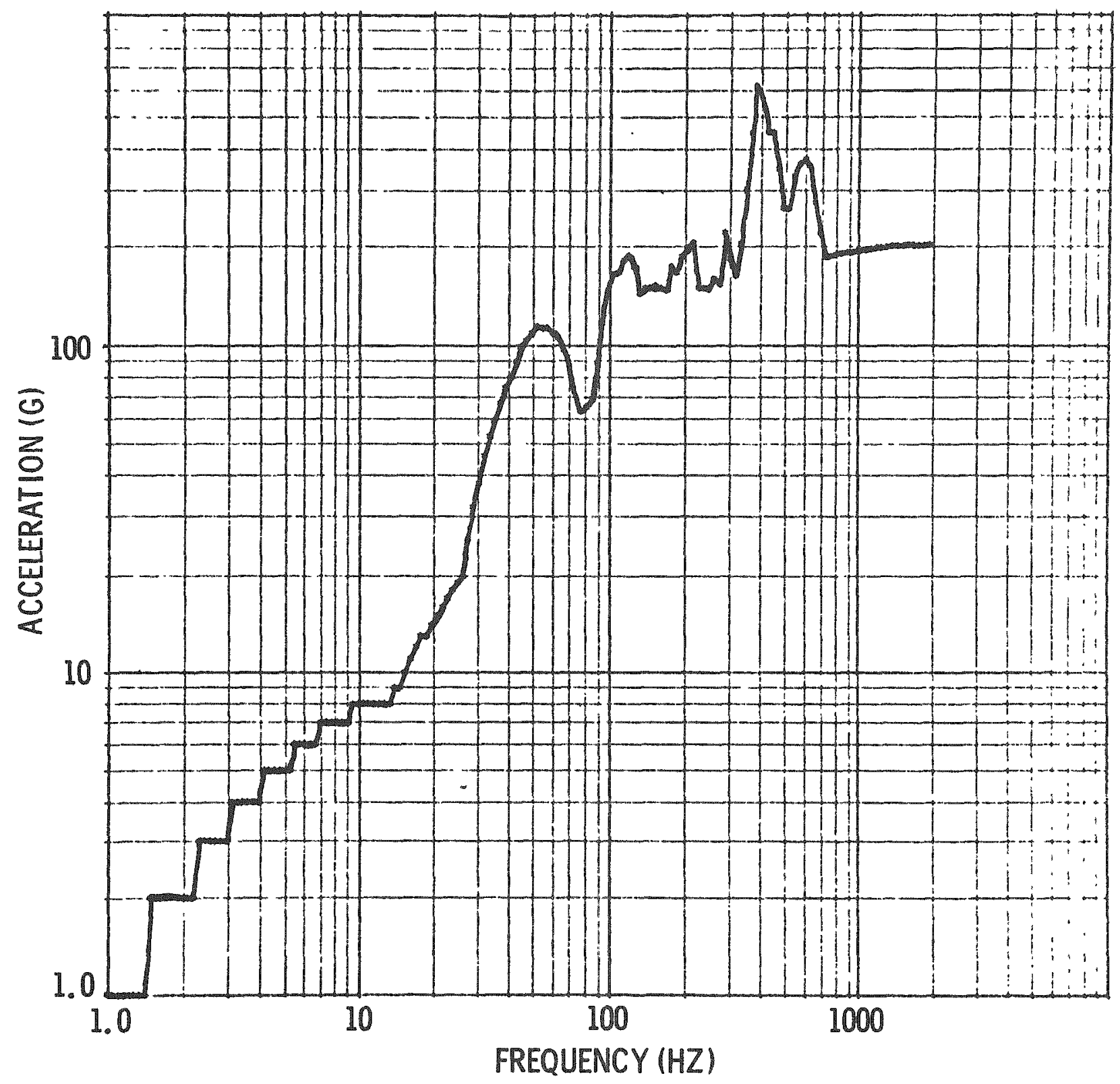

Figure And. Response Spectrum Analytical Results

Spent Fuel Cask System with $3.2 \mathrm{~mm}(1 / 8$ inch) Spacing, $890,000 \mathrm{~N}(200,000$ pound)

Cargo, $17.78 \mathrm{~km} / \mathrm{hr}$ (11.05 mph) Impact

Velocity, 3 percent Damping, Longitudinal Axis 


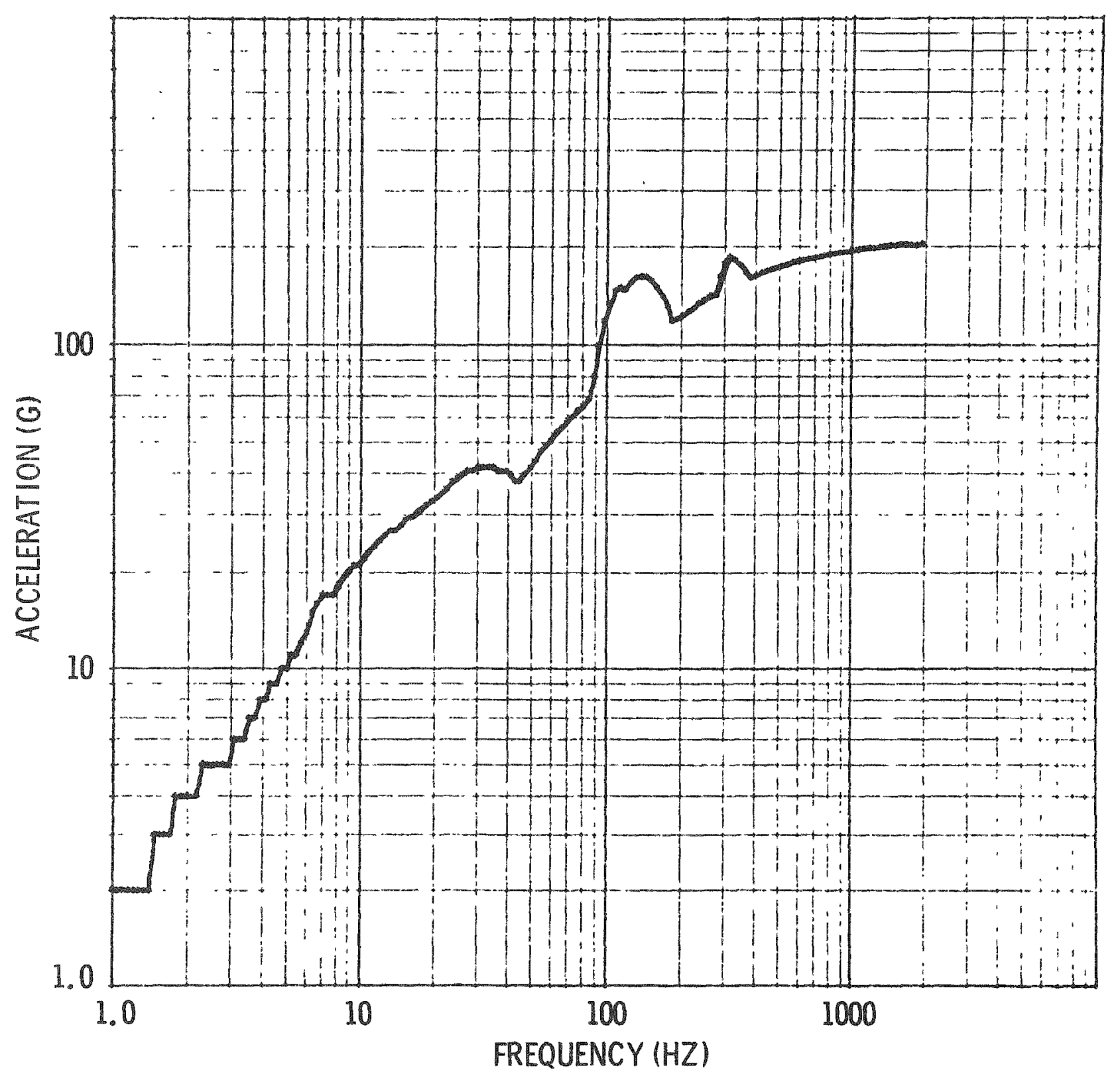

Figure $A-5$. Response Spectrum Analytical Results

Spent Fuel Cask System, Cargo Tied Down, $178,000 \mathrm{~N}(40,000$ pound) Cargo, $17.78 \mathrm{~km} / \mathrm{ht}$ (11.05 mph) Impact Velocity, 3 percent Damping, Longitudinal Axis 


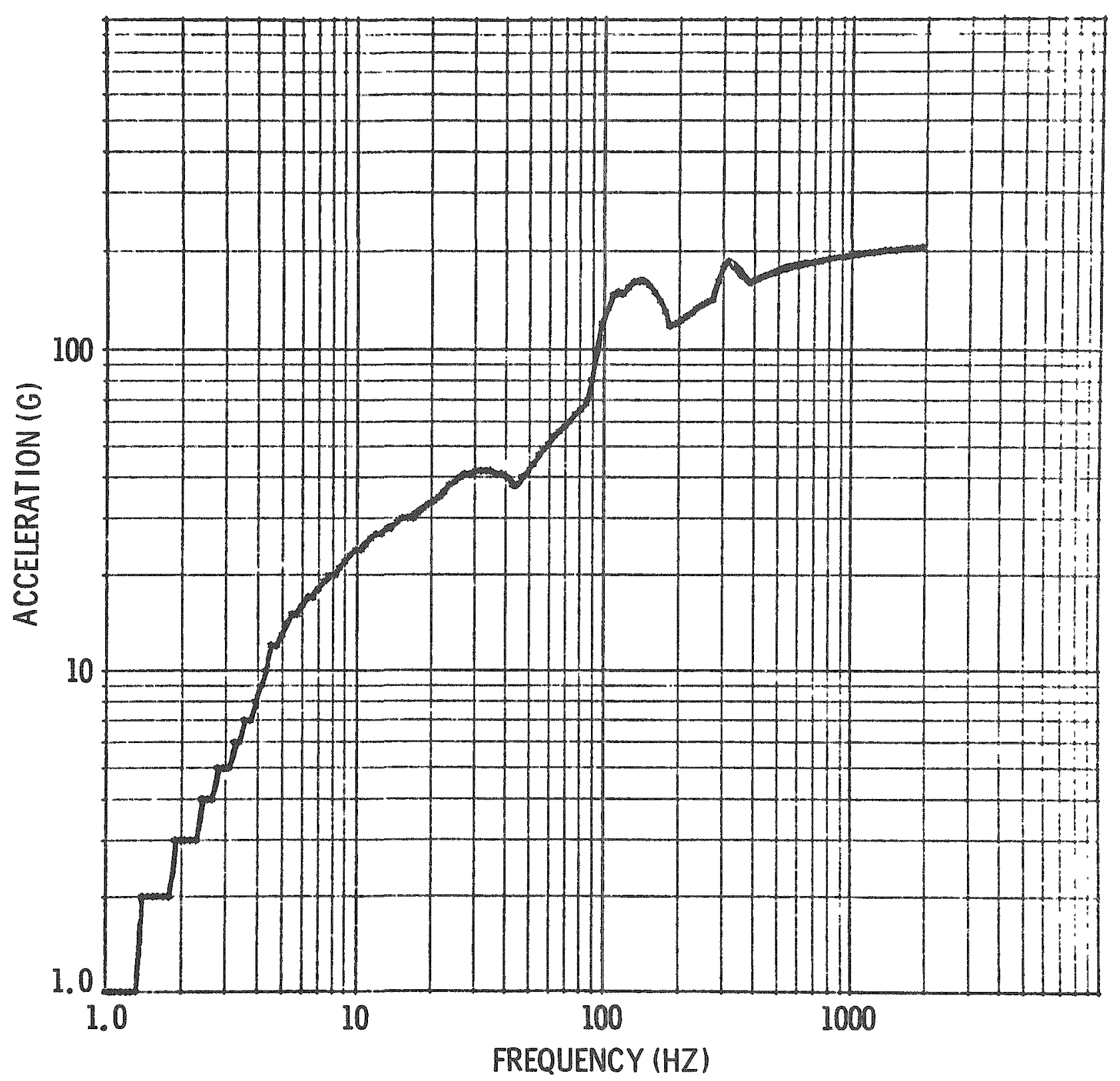

Figure A-6. Response Spectrum Analytical Results

Spent Fuel Cask System, Cargo Tied Down, $445,000 \mathrm{~N}(100,000$ pound) Cargo, $17.78 \mathrm{~km} / \mathrm{hr}$ (11.05 mph) Impact Belocity, 3 percent Damping, Longitudinal Axis 


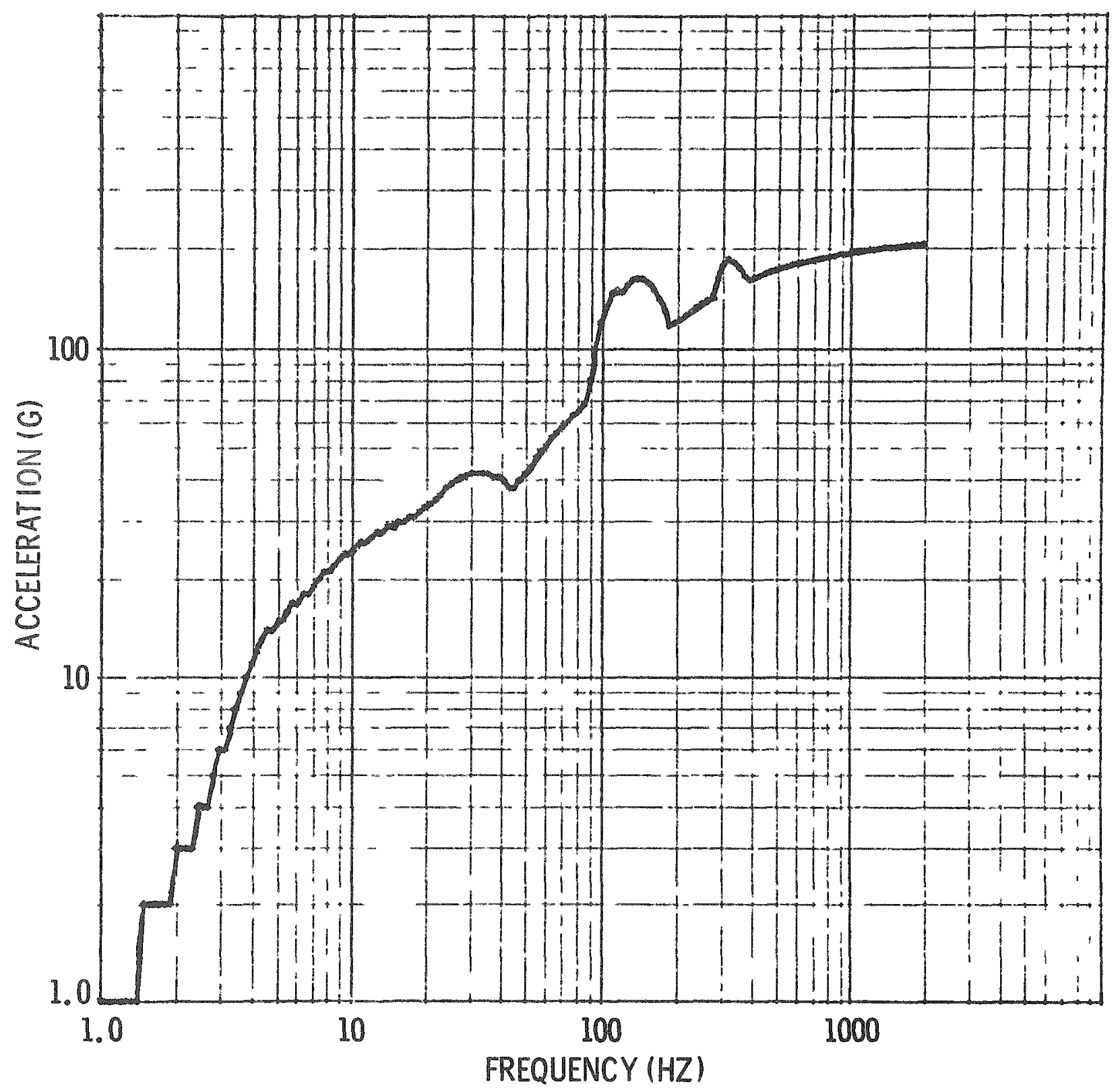

Tiuure A-7. Response Spectrum Analytical Results

Spent Fuel Cask System, Cargo Tred Down, $712,000 \mathrm{~N}(160,000$ pound ) Cargo, $17.78 \mathrm{~km} / \mathrm{hr}$ (1].05 mph) Impact Velocity, 3 percent Damping, Longitudinal Axis 


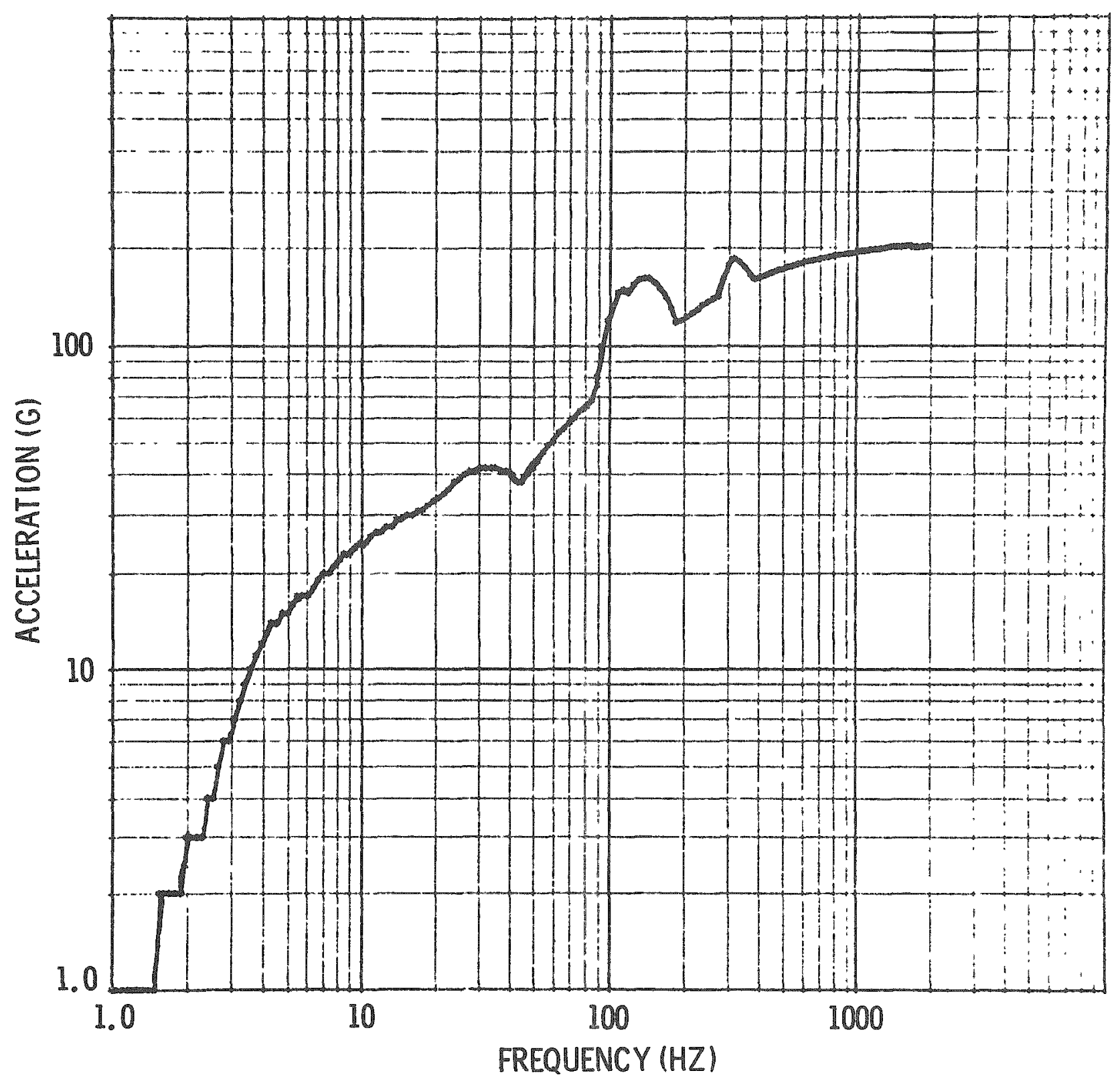

Figure $A-8$. Response Spectrum

Analytical Results

Spent Fuel Cask System, Cargo Tied Down,

$890,000 \mathrm{~N}(200,000$ pound) Cargo, $17.78 \mathrm{~km} / \mathrm{hr}$

(11.05 mph) Impact Velocity, 3 percent

Damping, Longitudinal Axis 


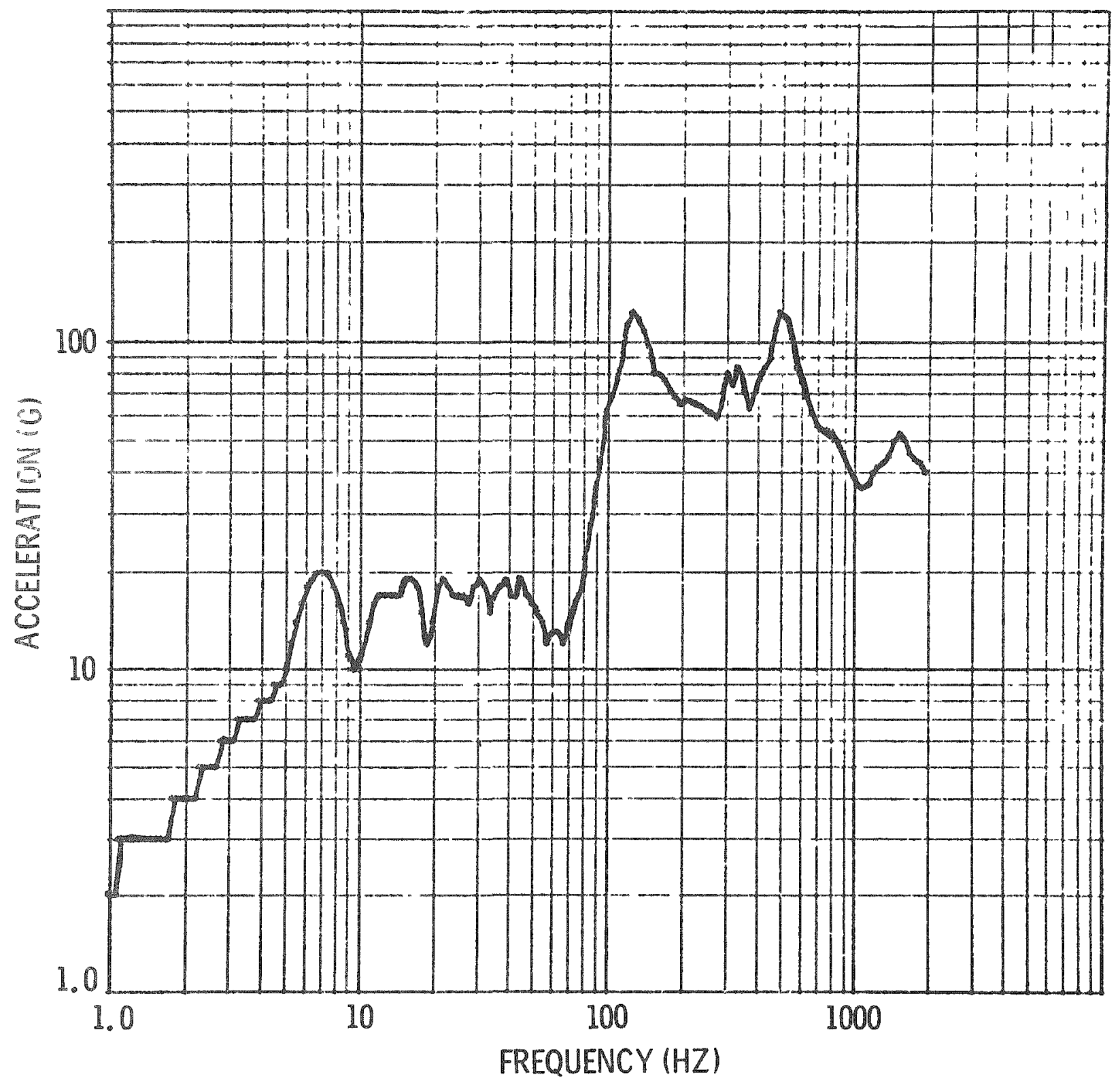

Fiłure A-9. Response Spectrum Analytical Results

ATMX Car, Standard Draft Gear, 178,000 N $(40,000$ pound) Cargo, $17.78 \mathrm{~km} / \mathrm{hr}$ (11.05 mph) Impact Velocity, 3 percent Damping, Longitudinal Axis 


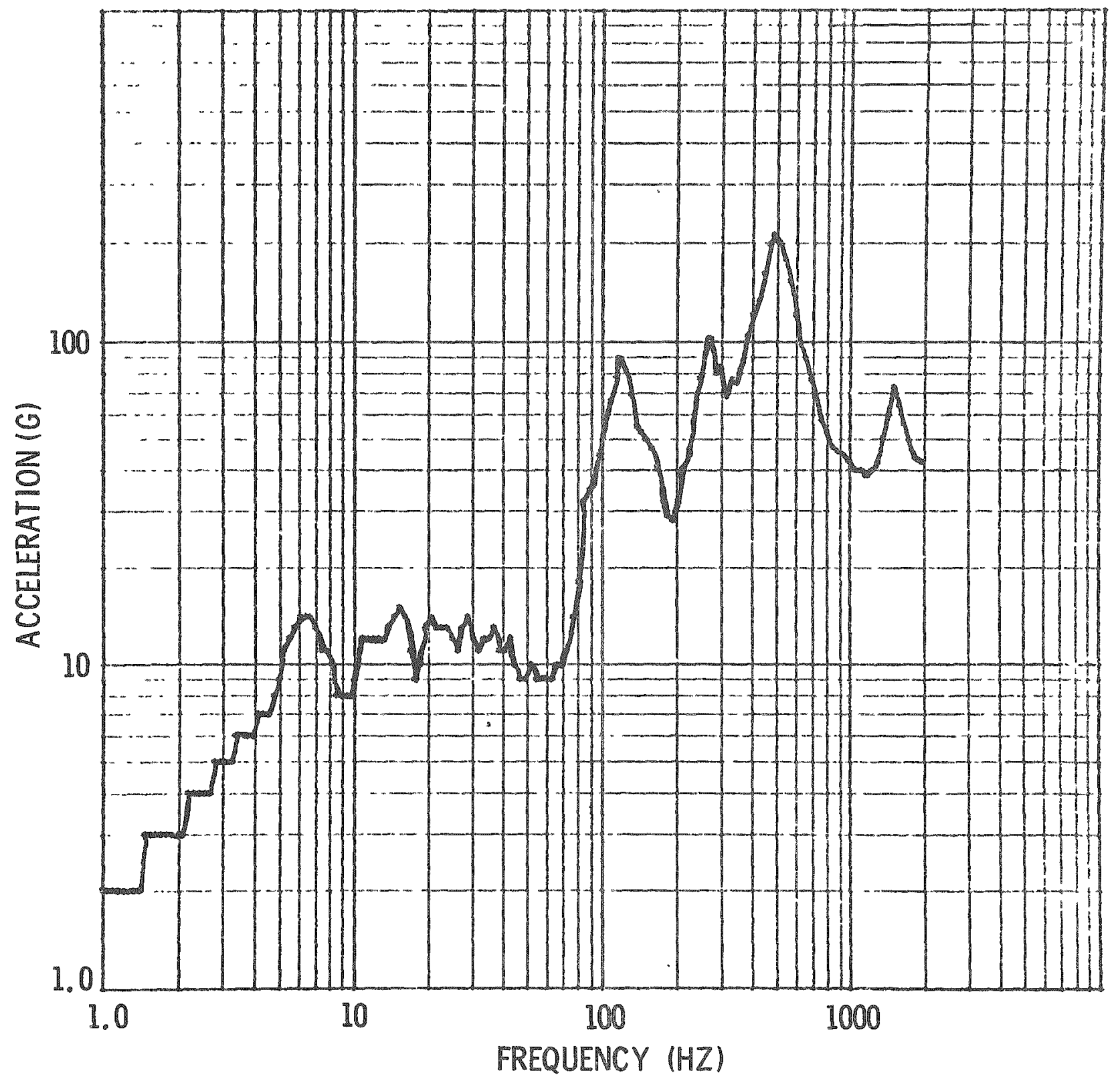

Figure A-10. Response Spectrum Analytical Results

ATMX Car, Standard Draft Gear, 451,000 N

(101,300 pound) Cargo, $17.78 \mathrm{~km} / \mathrm{hr}$ (11.05 mph) Impact Velocity, 3 percent Damping, Longitudinal Axis 


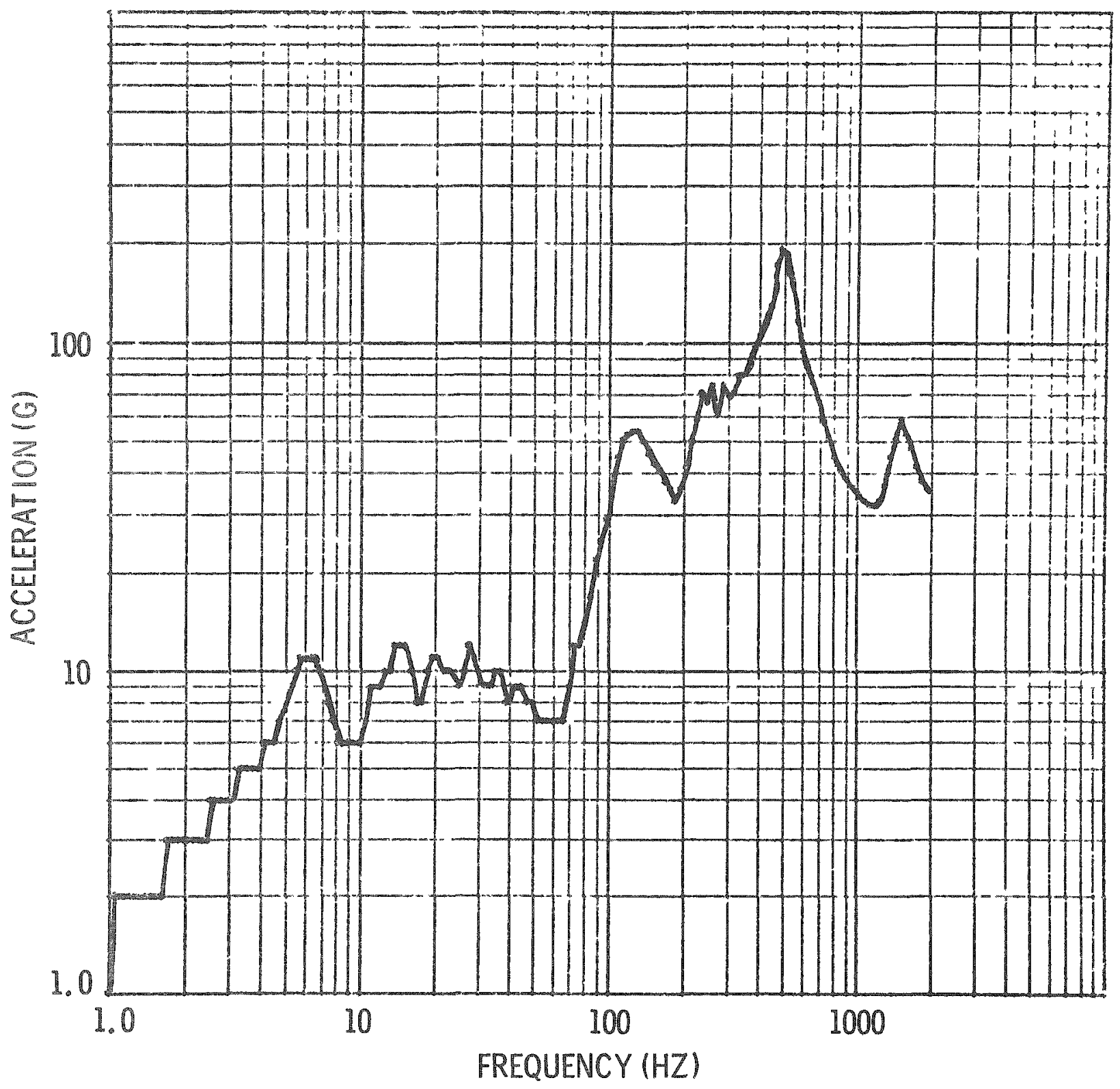

Fiyure $A-11$. Response Spectrum Analytical Results

ATMX Car, standard Draft Gear, $712,000 \mathrm{~N}$

(160,000 wound) Cargo, $17.78 \mathrm{~km} / \mathrm{hr}(11.05$

mph) Impact Velocity, 3 percent Damping,

Longitudinal Axis 


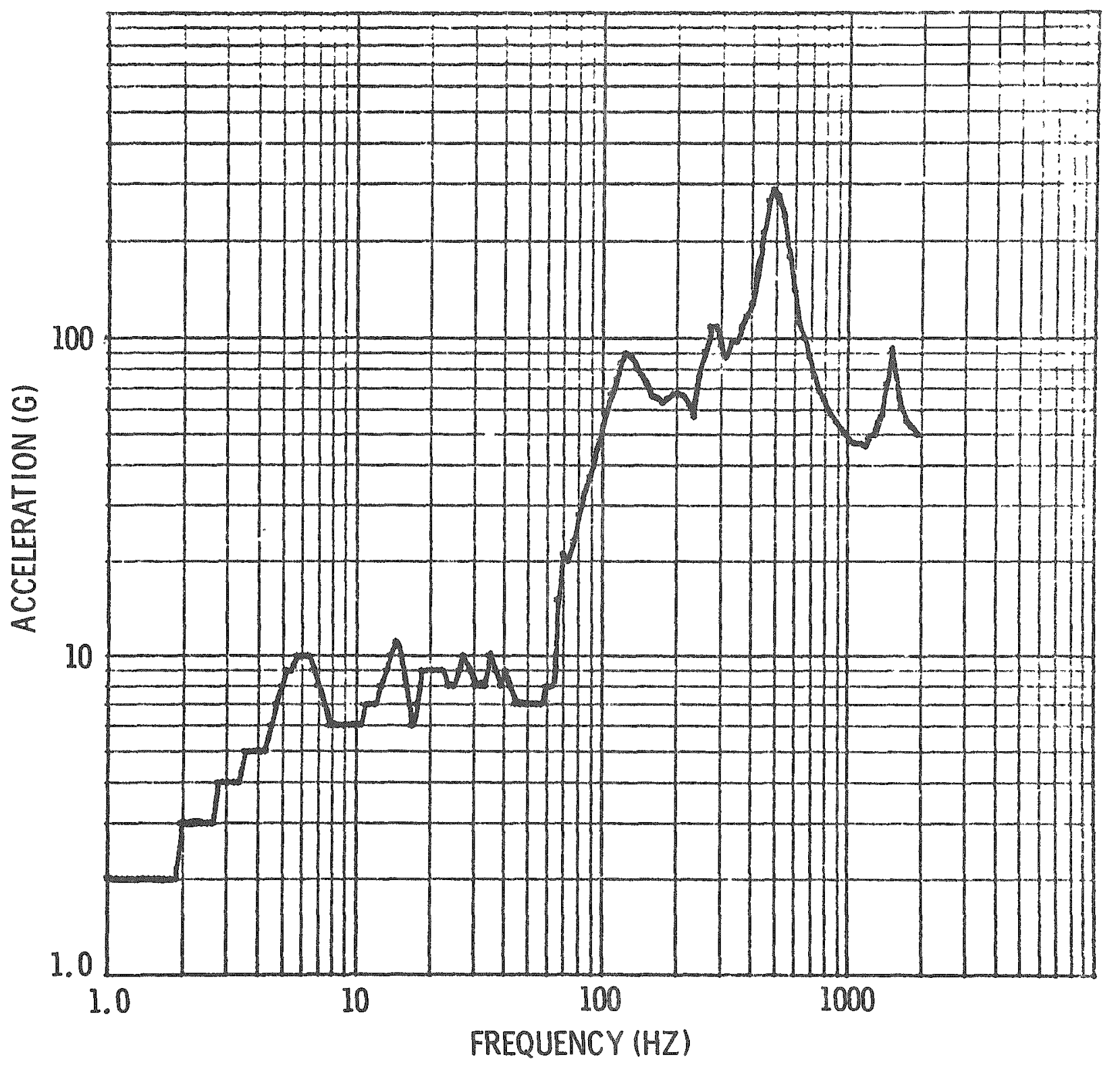

Figure A-12. Response Spectrum Analytical Results

ATMX Car, standard Draft Gear, $890,000 \mathrm{~N}$

$(200,000$ pound) Cargo, $17.78 \mathrm{~km} / \mathrm{hr}(11.05$

mph) Impact Velocity, 3 percent Damping,

Longitudinal Axis 


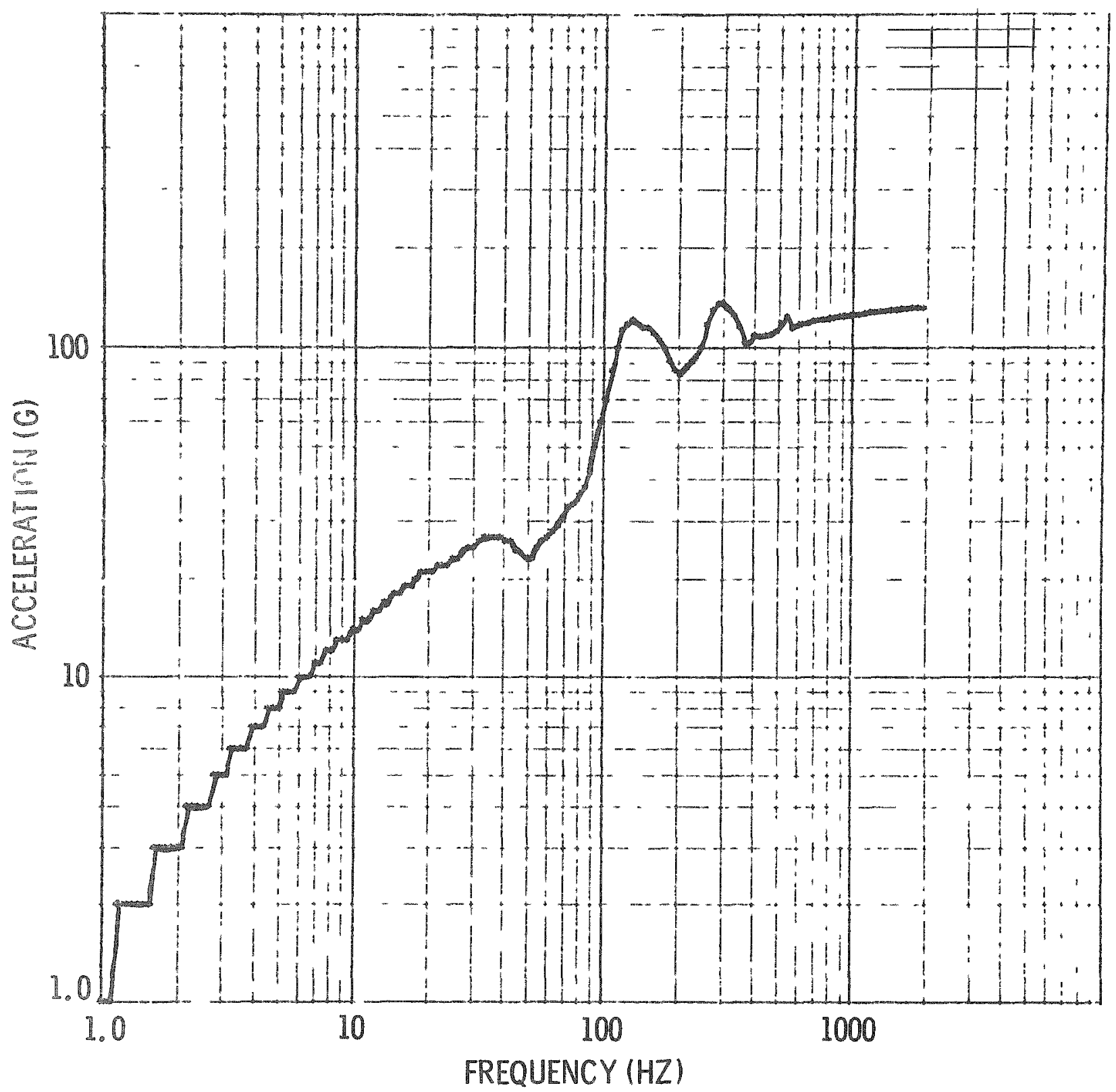

Figure $\mathrm{A}-13$. Response spectrum Anulytical Results

ATMX Car, shock Attenuating Couplers, $178.000 \mathrm{~N}(40,000$ pound) Cargo, $17.78 \mathrm{~km} / \mathrm{hr}$ (11.05 mph) Impact Velocity, 3 percent Dampina, Longitudinal AxIs 


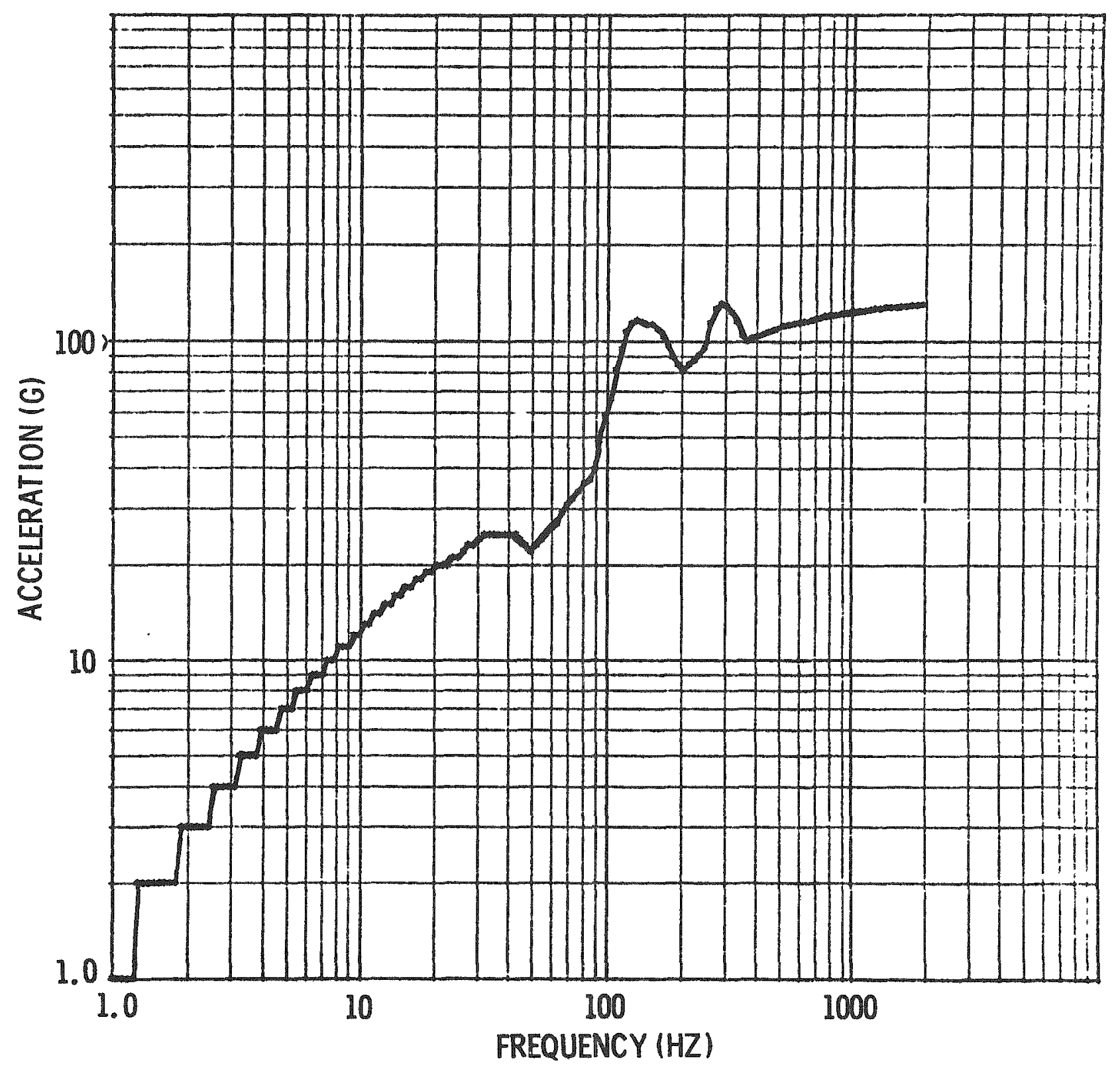

Figure A-14. Response Spectrum Analytical Results

ATMX Car, Shock Attenuating Couplers,

$451,000 \mathrm{~N}(101,300$ pound) Cargo, $17.78 \mathrm{~km} / \mathrm{hr}$

(11.05 mph) Impact Velocity, 3 percent

Damping, Longitudinal Axis 


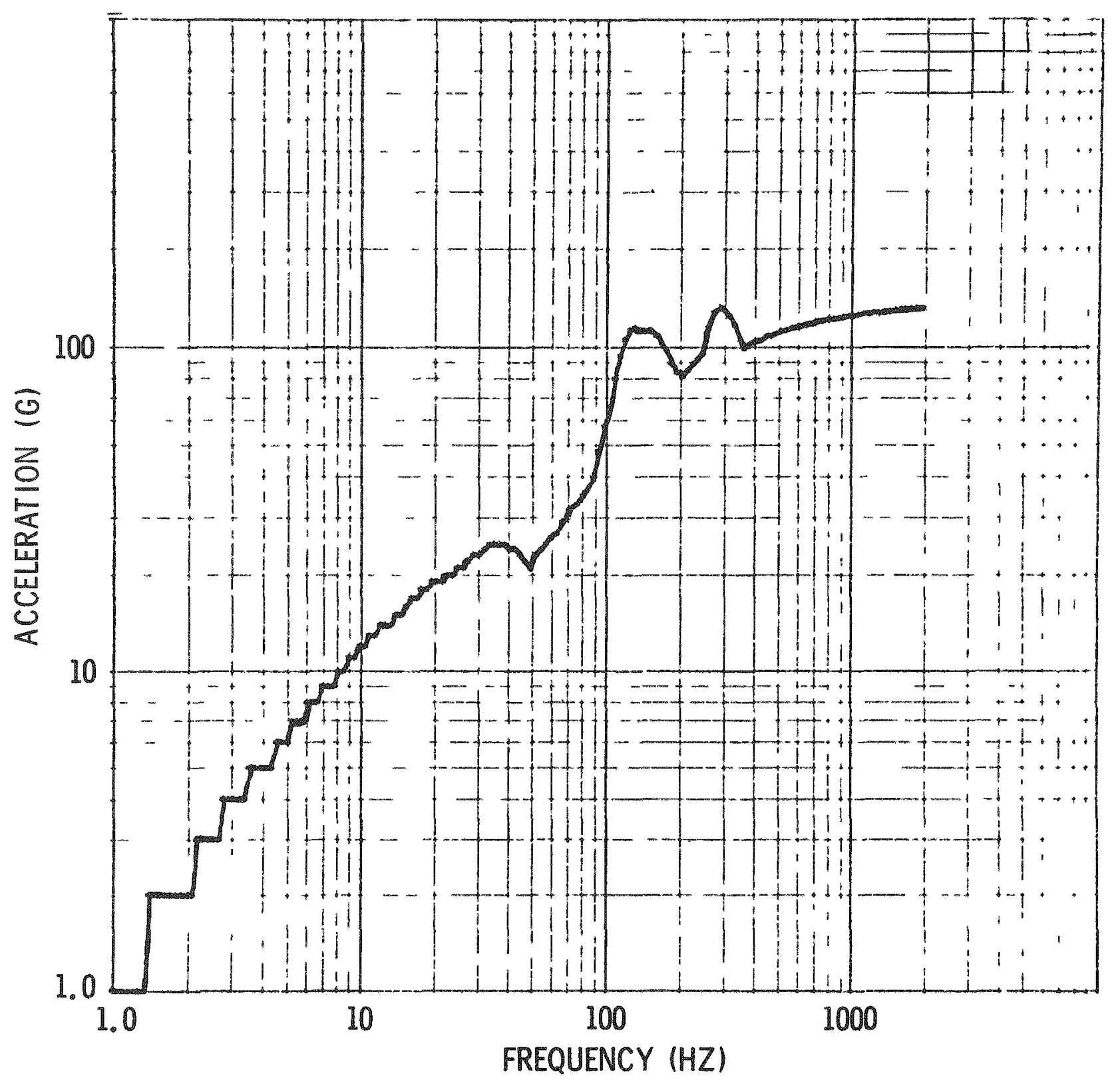

Figure A-15. Response Spectrum Analytical Results

ATMX Car, Shock Attenuating Couplers, $712,000 \mathrm{~N}(160,000$ pound) Cargo, $17.78 \mathrm{~km} / \mathrm{hr}$ (11.05 mph) Impact Velocity. 3 percent Damping, Longitudinal Axis 


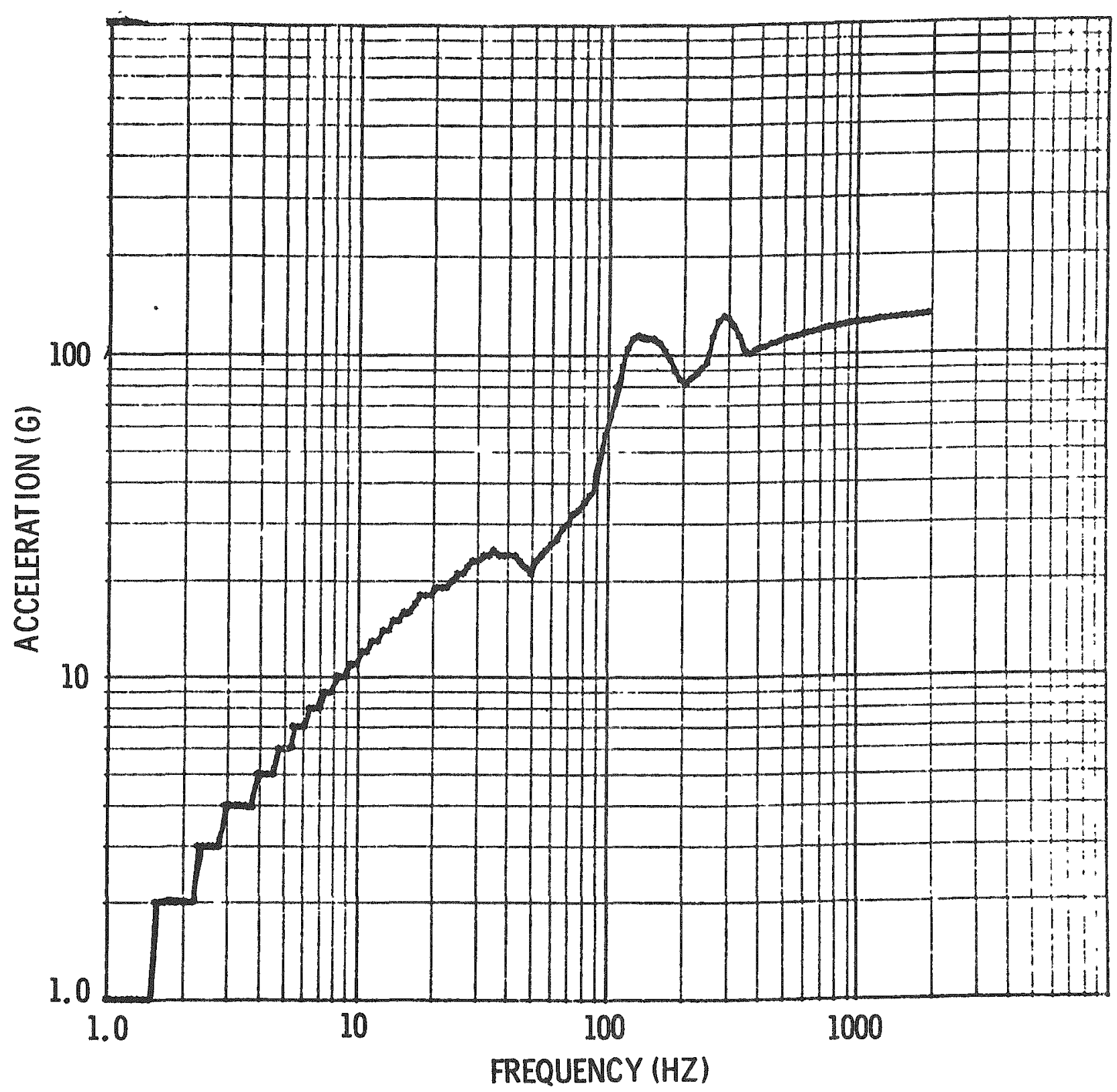

Figure A-16. Response Spectrum Analytical Results

ATMX Car, Shock Attenuating Couplers, $890,000 \mathrm{~N}(200,000$ pound) Cargo, $17.78 \mathrm{~km} / \mathrm{hr}$ (11.05 mph) Impact Velocity, 3 percent Damping, Longitudinal Axis 


\section{DISTRIBUTION}

U. S. NRC Distribution System

Distribution Category NRC-12 (238 copies)

Attn: Robert Wade

Washington, D.C. 20555

D. A. Nowlin, Director

Special Programs Division

U. S. Energy Research and Development Administration

Albuquerque Operations office

Albuquerque, New Mexico 87115

William Lahs

Safer Division

U.S. Nuclear Regulatory Commission

Washington, D.C. 20555

1000

1200

1280

1281

1282

1282

1284

1284

5000

5100

5200

5400

5430

5431

5431

5432

5432

5433

5433

5433

5700

5711

5800

8266

3141

3151

G. A. Fowler

W. A. Gardner

T. B. Lane

S. W. Key

T. G. Priddy

C. F. Magnuson (10)

R. T. Othmer

L. T. Wilson (10)

A. Narath

J. K. Galt

E. H. Beckner

A. W. Snyder

R. M. Jefferson

R. E. Nickell

W. A. Von Riesemann

L. I. Bonzon

R. E. Luna

R. B. Pope

J. M. Freedman

H. R. Yoshimura

J. M. Scott

E. I. Harley

R. S. Claassen

E. A. Aas (2)

C. A. Pepmueller/Actg/

W. L. Garner (3)

For ERDA/TIC (Unlimited Release) 